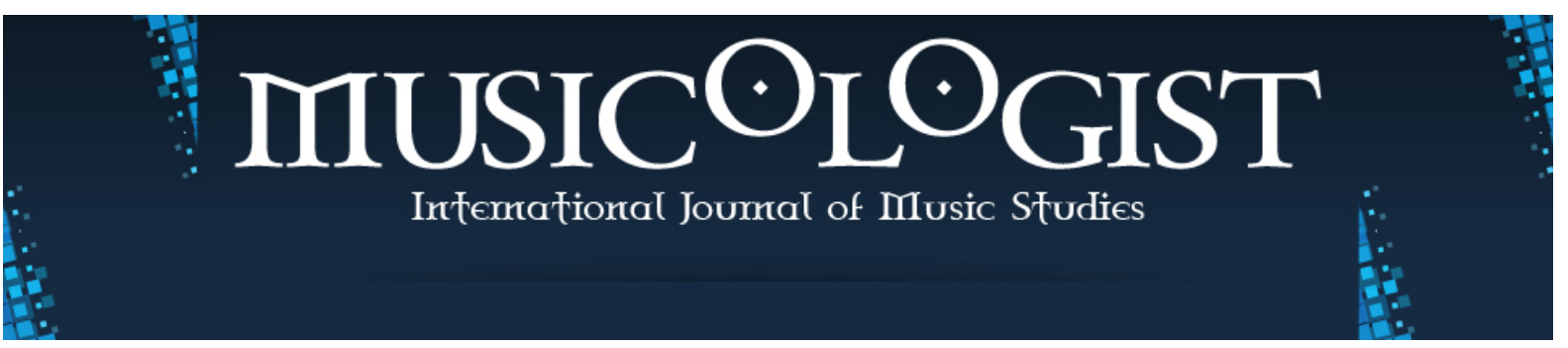

Karadeniz Technical University State Conservatory @ 2017

Volume 1 Issue $1 \quad$ December 2017

Research Article

Musicologist 2017. 1 (1): 52-94

DOI: $10.33906 /$ musicologist.373163

NINO RAZMADZE

V. Sarajishvili Tbilisi State Conservatoire, Georgia

nino.razmadze@conservatoire.edu.ge

orcid.org/0000-0002-7871-5394

\title{
Larchemi/Soinari - The Georgian Panpipe
}

\section{ABSTRACT}

This article focuses on the panpipe, one of the ancient instruments of the Georgian traditional instrumentarium. Some Georgian traditional instruments remain popular today, with playing and construction techniques still preserved. Others, however, have disappeared from everyday life and stage folklore. Today, an instrument considered as one of the most ancient Georgian traditions - the panpipe, which we can discuss based on documentation and materials from the first half of the $20^{\text {th }}$ century - is among those that have disappeared from everyday life.

The article aims to collate information about the instrument from different works by various researchers, and also to study its organological, ethnographic and musical features. It offers in-depth analysis of audio recordings and notated scores from fieldwork expeditions of the 1930s and 1950s.

Nowadays, there are some attempts in the regions as well as in the capital of Georgia to restore this instrument, although construction and repertoire are significantly different from the traditional forms.

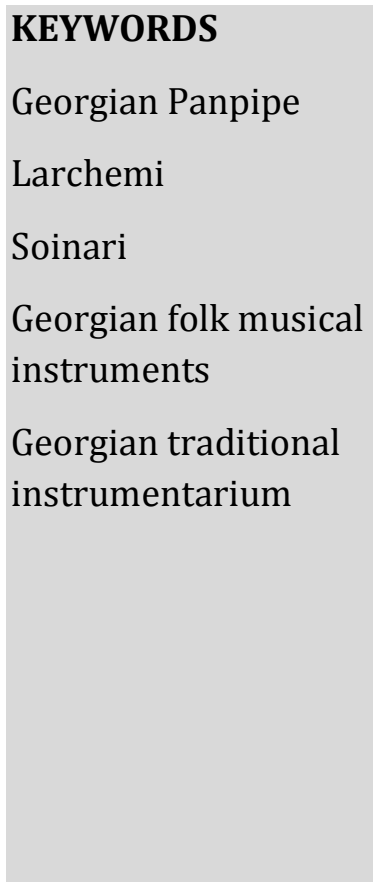




\section{Introduction}

The Georgian panpipe was widespread throughout the territory of historical Colchis, particularly in Samegrelo, where it was known as larchemi (in the Jvari and Khobi area) and Guria, where it was known as soinari/solinari (in the Chokhatauri region, figure 1). We have proof that a panpipe known as ostvinoni existed in Lazeti too ${ }^{1}$. In addition, the instrument may have spread into Abkhazia and Kvemo Imereti (Rosebashvili, 1960: 49); however, there is no concrete proof of this in the sources ${ }^{2}$. Two other terms meaning 'panpipe' have been recorded in the literature: sastsrapo (in English: the urgent, in Samegrelo), which means 'gunpowder flask' (Steshenko-Kuptina, 1936: 55-56), and sastvinveli (whistling) (Alavidze, 1978: 83; Orbeliani, 1993: 55).

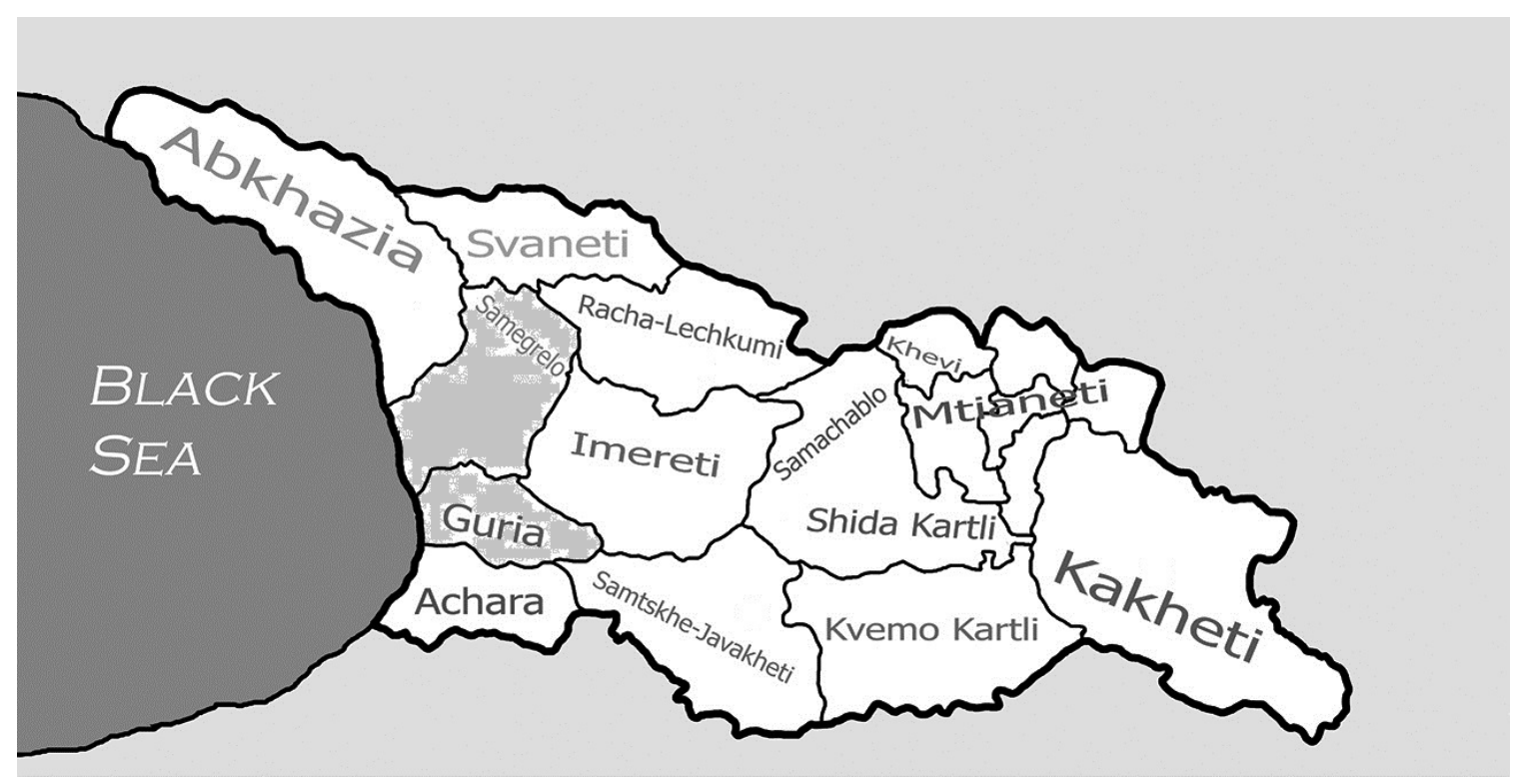

Figure 1. The map of Georgia.

A number of Georgian researchers have written about the Georgian panpipe (D. Arakishvili, I. Javakhishvili, V. Steshenko-Kutpina, S. Makalatia, K. Rosebashvili, 0. Chijavadze, M. Shilakadze, G. Simvulidi, N. Mshvelidze, T. Zhvania, I. Zhghenti, etc.). The most important works are those of V. Steshenko-Kuptina (1936), D. Arakishvili (1940) and K. Rosebashvili (1960, 1975, 1981, 1985, 1986). In addition, a very important ethnographic report is given by Sergi Makalatia (1941). Musical materials are analyzed

1 The existence of the panpipe in Lazeti is confirmed in one source only (Steshenko-Kuptina, 1936: 36, 153).

${ }^{2} \mathrm{~K}$. Rosebashvili has noted that the larchemi was used in the ritual to "catch the soul" of the dead in Abkhazia, as well in Samegrelo (Rosebashvili, 1960: 51). We must note that there is only one village, Kokhnari, where the soinari was recorded. The village borders Imereti, hence the instrument may have existed in this region as well. 
by Valentina Steshenko-Kuptina (1936: 231-237), Giorgi Simvulidi (1978: 34-45), Tinatin Zhvania (2006: 24-41) and Ivane Zhghenti (2016: 103-123). To date, there is only one scholarly article available in English (Mshvelidze, 2003), together with a short entry in the Grove Dictionary of Musical Instruments (Chkhikvadze, 2014: 20; Razmadze, 2014: 260-261).

Since the instrument has disappeared from life in the villages, we have to be satisfied with the reports about its role in traditional everyday life, the technology of construction, the nature of ensemble playing, and other features provided by the authors mentioned above. Fieldwork expedition materials - in particular, audio and score samples - are provided by Mshvelidze (soinari - 1931), Steshenko-Kuptina (larchemi and soinari - 1936), Chijavadze (larchemi - 1959) and Rosebashvili (larchemi - 1958; soinari - 1959); in total, there are 21 scores and 24 audio samples. There are 34 different items represented among the 45 samples; 11 score samples match the audio versions (see the list of score and audio examples below).

There are a number of legends about the origins of the panpipe. The most popular is the legend about the Greek god Pan. Another Greek myth is interesting, telling us about the king of the Georgian tribes, Mita: "In the $8^{\text {th }}-7^{\text {th }}$ century BC, in the Mushki (Meskhi) kingdom, great musical spectacle competitions were held. Mita, the King of Mushki, was himself considered to be the creator and disseminator of the panpipe, and also the supporter and referee of those playing it" (Janelidze, 1965: 50).

A Hittite bas-relief showing an image of a man in chokha (traditional Georgian costume) with wheat and panpipe (figure2, Steshenko-Kuptina, 1936: 64-65) ${ }^{3}$, allowed the researchers K. Rosebashvili and T. Zhvania to confirm that in ancient times tribes related to today's Georgians had the panpipe (Rosebashvili, 1960: 50; Zhvania, 2006: 27).

\footnotetext{
${ }^{3}$ V. Steshenko-Kuftina bases on the French publication - Perrot et Chiptez. Histoire de l'art dans l'antiquitê, vol. IV, p. 561. The reseracher notes that the bas-relief dates back no earlier than VIIVIII centuries.
} 


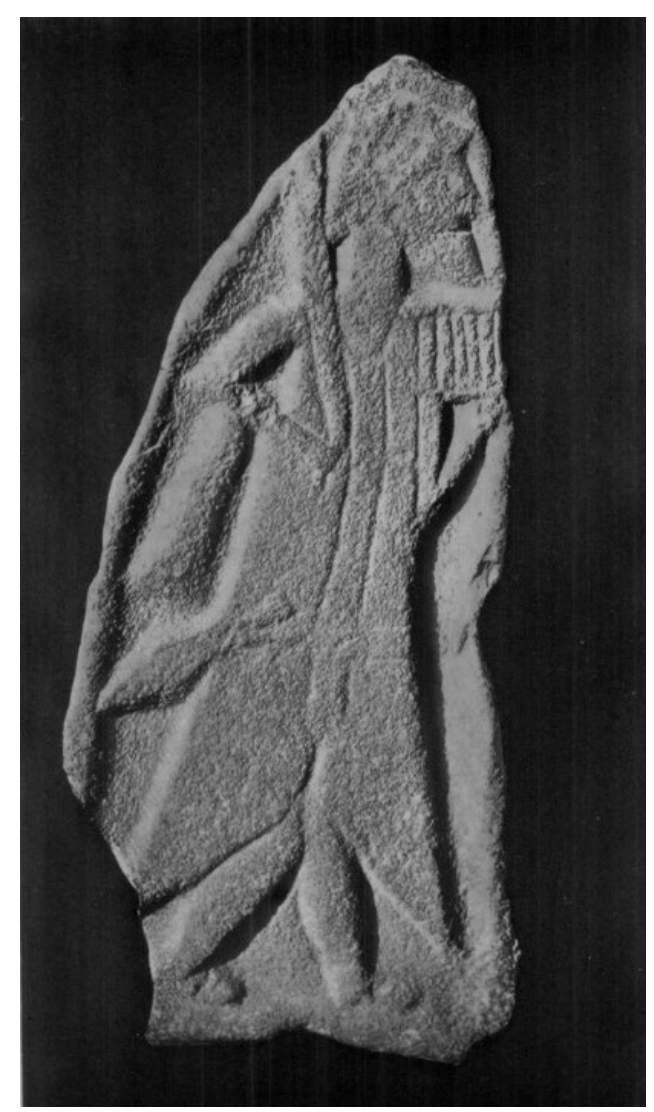

Figure 2. Hittite bas-relief from Roum-Qalah (Стещенко-Куфтина, 1936: 64).

The $2^{\text {nd }}$ century mosaic figure of Pan playing the panpipe, discovered in Dzalisi near Mtskheta, is interesting, since scientists think it may be the ochopintre (ochokochi/ochopintre (Georgian: goatman) playing the salamuri/flute (figure 3, Chikhladze, 2013: 88).

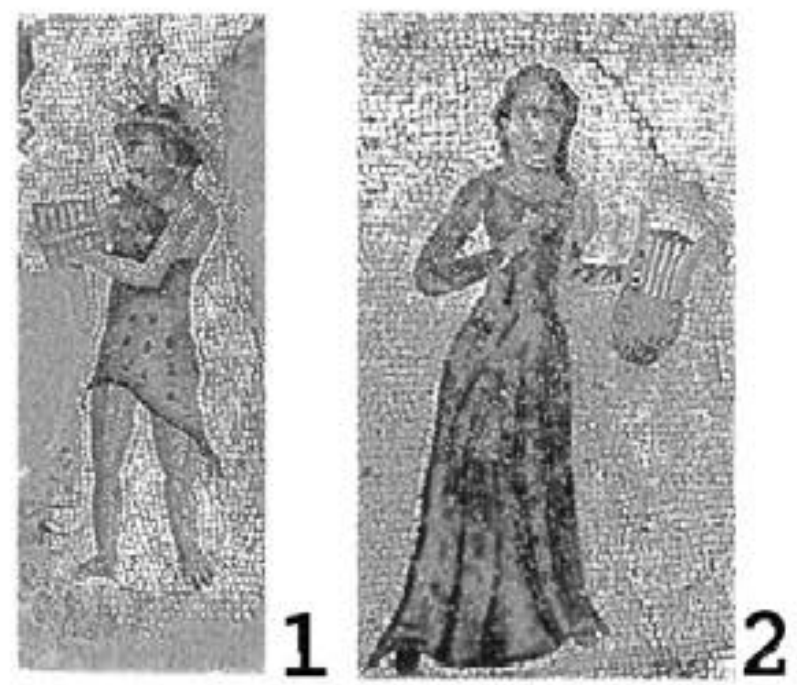

Figure 3. The mosaic figure of Pan playing panpipe and a woman with a lyra. $2^{\text {nd }}$ century AD (Chikhladze, 2013: 88). 
But, since, first of all, the ochopintre is not an Eastern mythological character even though discovered near Mtskheta, and, secondly, the main images on the colorful mosaic of the temple-palace are Dionysus, Ariadne and a woman with an instrument similar to Greek lira (Chikhladze, 2013: 70), this may be the Greek Pan, not the Georgian ochopintre.

I. Zhghenti and M. Shilakadze make a very interesting point about the human figure playing a double-pipe musical instrument depicted on the golden hanger in the 'Khaishi treasure' discovered in Svaneti (Zhghenti, 2016: 106; Shilakadze, 2007: 36). Dating from the 1st-2nd centuries AD (figure 4, Javakhishvili, 1958: 155), the golden hanger was considered to be the production of a local workshop (Chikhladze, 2013: 90).
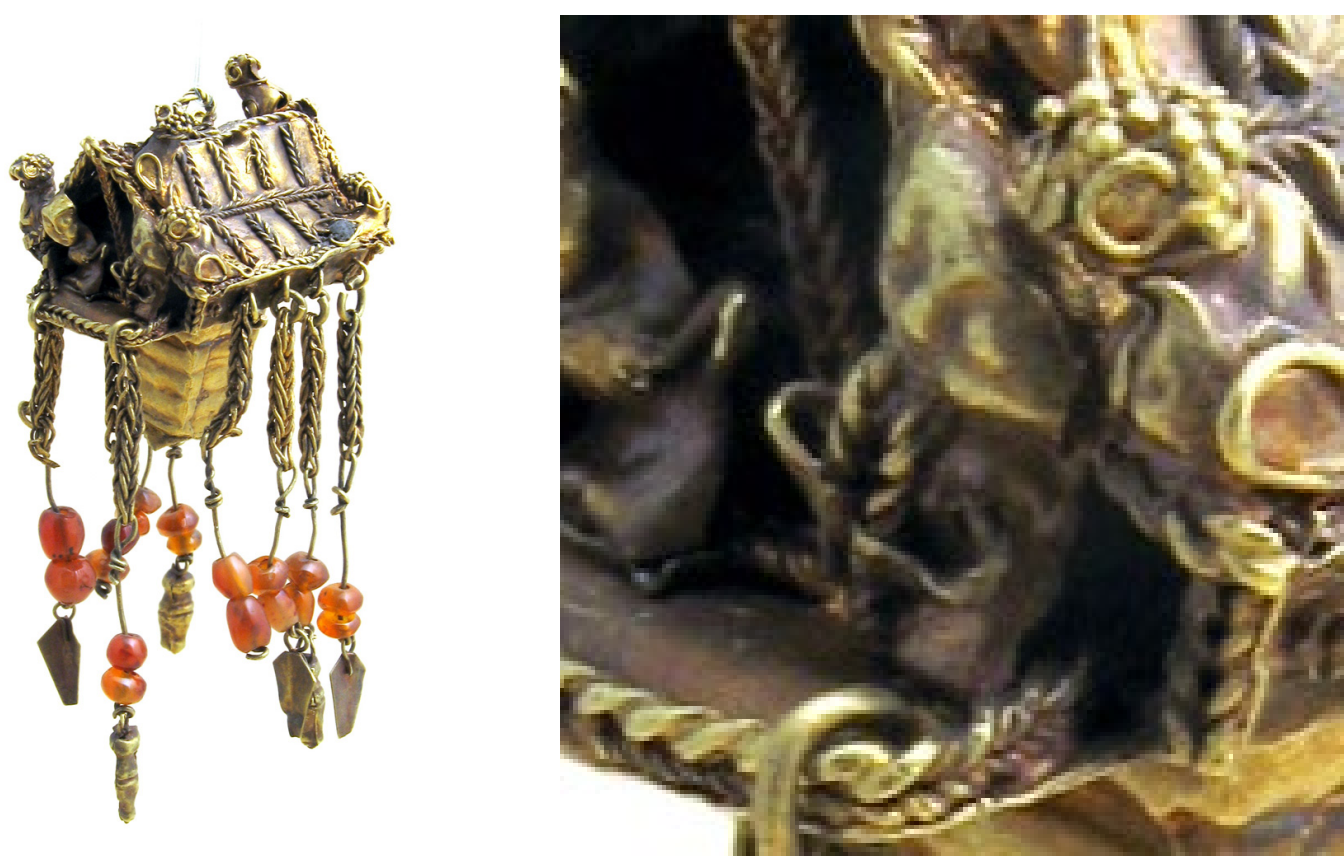

Figure 4. 'Khaishi treasure' discovered in Svaneti. $1^{\text {st }-2^{\text {nd }}}$ century AD (Copyright the Georgian National Museum).

I think this instrument is more similar to the Greek aulos than to the panpipe. Discovering an instrument similar to the Greek aulos in Svaneti is to be expected, because some centuries before this period, there is evidence of Greek colonies and influences in the region. 


\section{Nomenclature for the Instrument}

Four out of five names for the Georgian panpipe (larchemi, soinari, ostvinoni, sastvineli, sastsrapo) originated in Georgia.

Apparently, literary sources refer to it as soinari/solinari. Sulkhan-Saba Orbeliani (17th century) defines the meaning of solinari in his Georgian language dictionary ${ }^{4}$ also, to describe the process of playing panpipe by musicians in the work Traveling in Europe, he uses the term soinari (Orbeliani, 1940: 50). It is important that this tendency also shows itself in the scientific literature. For instance, D. Arakishvili the term soinari used to define Gurian and Megrelian panpipes (Arakishvili, 1940: 5-8; translation by Gr.

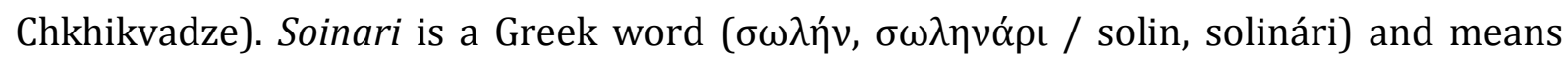
'water pipe' in Georgian (Orbeliani, 1993: 165).

It is extremely interesting that in the 11th century work by Basili of Caesarea, 'Hexaëmeros' (Six Days of Creation), translated from Greek into Georgian by Giorgi Mtatsmindeli, the term solinari is defined as panpipe (Abuladze, 1964: 42). ${ }^{5}$ In the original Greek, to explain the arrangement of celestial bodies the talk is about twin vessels put together- ' $\tau \tilde{\omega} v \kappa \alpha ́ \delta \omega \nu$ ' (dishware, vase, small barrel - in the plural). ${ }^{6}$ Instead of twin vessels Giorgi Mtatsmindeli apparently uses the name of the instrument Solinari, disseminated in Georgia at the time. So the term has not been directly translated but replaced with its Georgian analog - familiar to Georgians with its local name.

The term larchemi means arundo (giant cane plant) in Megrelian. Indeed, in mountain areas of Samegrelo there are species of this plant named larchema used as material for making the instrument.

So far we have only one source about the panpipe (ostvinoni) spread in Lazeti provided by Iskander Tsitashi (İskender (Alexander) Chitaşi) (Steshenko-Kuptina, 1936: 36). Other researchers (Rosebashvili, Shilakadze, Mshvelidze, etc.) refer to the notes of Steshekno-Kuptina about the Laz ostvinoni.

\footnotetext{
4 "Stvirni shetskobit shetsebulni" (Orbeliani, 1993: 166).

${ }^{5}$ http://titus.uni-frankfurt.de/texte/etca/cauc/ageo/bascaes/baskes6d/basket.htm

${ }^{6}$ I wish to thank Ketevan Matiashvili, who helped me find and translate the text.
} 
On the one hand, the term ostvinoni can be connected to ancient Greek (in the standard

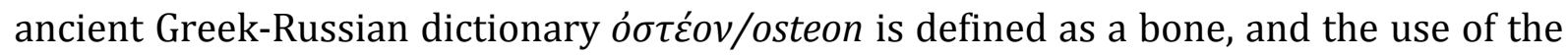
term to indicate bone flutes may have originated from that (Dvoretski, 1958: 1200); ${ }^{7}$ on the other hand, it sounds like the Georgian word stvena (whistle); most Laz informants defined ostvinu as 'sliding' (for example, ice sliding, skiing, etc.) ${ }^{8}$, while others recalled its ancient meaning, whistling 9 , although they did not confirm the existence of a pan-like instrument in Lazeti. There is a note by the young researcher Giorgi Kraveishvili that Laz consultants Narime Helimish and Muhittin Memişoğlu confirmed the existence of the ostvinoni in Lazeti (Kraveishvili, 2011: 126). In private conversation with the researcher I have verified that neither of these informants remembered the term ostvinoni (hence, the term used here is chosen by the author), and the researcher could not determine which instruments they were talking about - panpipe or tulum pipes (widespread among the Georgian population living within the territory of Turkey, and significantly different from the panpipe) (Saygun, 1937: 4710, Figure5). For now, the existence of the ostvinoni in Lazeti cannot be confirmed without more evidence.
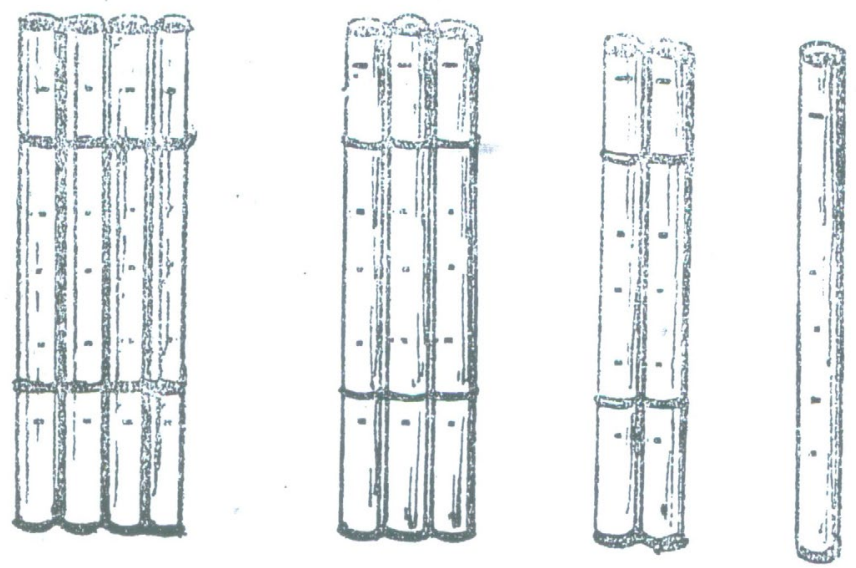

Figure 5. Pipes of tulum (chimoni) (Saygun, 1937: 47).

The local term sastvinveli, meaning Georgian panpipe, is mentioned in old Georgian translations of the Bible. D. Alavidze considered it the analog of the Laz ostvinoni

\footnotetext{
7 I wish to thank Ketevan Matiashvili, who helped me work with the dictionary.

${ }^{8}$ I checked the information in a contemporary Laz-Turkish-English e-dictionary, where the same definition is given: ostvinu//kaydırmak//to slide, to be swift http://www.nenapuna.net/

9 Muhsin Senturk, 1953; Laz dictionary: http://www.ice.ge/liv/liv/lazur.php. See: osthvinu (whistle), ostvinu (whistle), stvinei (with whistling), nostvine (whistled), etc.

${ }^{10}$ I am grateful to Abdullah Akat for providing me with this source.
} 
(Alavidze, 1978: 83). According to Sulkhan-Saba Orbeliani these were "pipes $(3,7$ Daniel)" (Orbeliani, 1993: 55).

I am curious as to whether the variety of instruments' names just reflects differences among dialects, or is evidence that these instruments were different from each other in terms of their construction, tunes and repertoires. Unfortunately, we can only discuss this question based on the sources we have concerning mutually shared and different characteristics between the Megrelian larchemi and the Gurian soinari.

\section{Materials and Construction}

The traditional way to make the panpipe was to use an arundo or larchema as the material of construction. Larchema is an arundo-like plant but notably different from it. It grows as a long thin stem, 10-12 millimiters in diameter. Inside the stem, there are sections separated by dividers, used to make the pipes of the instrument (Rosebashvili, 1985: 15). According to the Megrelian and Gurian masters, a larchemi made from an arundo does not produce a good sound, and playing it is not too satisfying (Makalatia, 1941: 256; Sharashidze, 2014: 86).

Besides arundo, Gurians used an arundo-like plant called the 'soinari bush' to make soinari (Sharashidze, 2014: 86).

The suitable time for cutting the material and making the instrument was the end of July, August and September. At that time the material is raw and does not crack even after being used for a long time; also, its voice is better (Makalatia, 1941: 256; Rosebashvili, 1985: 15). According to Steshenko-Kuptina, larchemi or soinari are made from one stem of arundo. The maker starts cutting from the bottom. The layout of the pipes has a shape of a rhombus that is cut into half; two bass pipes are the longest and are sandwiched in the middle, while the shorter ones are located on the sides. First of all, the maker cuts two bass pipes, then he cuts pipes one after another and tunes the sections to appropriate intervals of a third (Steshenko-Kuptina, 1936: 229). While cutting the pipes of larchemi there are no preset standards-a maker checks his progress aurally (Steshenko-Kuptina, 1936: 207).

The pipes arranged in a row are tied with the bark of a young cherry tree (Megrelian: khrali, balishi sartkeli [in English: pillow girdle]; Gurian: sartkeli [in English: girdle]) 
(Steshenko-Kuptina, 1936: 208; Makalatia, 1941: 257; Rosebashvili, 1960: 50; 1985: 16). According to the note by Nona Kobalia, to bind the pipes, cannabis or other tree barks were used ${ }^{11}$.

Larchemi and soinari were traditionally carried hanging round the neck with a ribbon loop (Megrelian: ghina, bunapali) (Steshenko-Kuptina, 1936: 210, image III; Rosebashvili, 1986: 18).

\section{Construction}

\section{Number of pipes and layout}

Researchers note a difference in size between the Gurian and Megrelian panpipes - the Megrelian panpipe is bigger compared to the Gurian (Steshenko-Kuptina, 1936: 208; Shilakadze, 1970: 19). However, according to Rosebashvili, there were two kinds of soinaris with different sizes in Guria -one small and the other even smaller, the so-called pocket soinari, which was played at nights while travelling (Rosebashili, 1985: 17). In addition, analysis of the sound frequencies from the audio recordings by Sh. Mshvelidze (1931) proves that there existed Gurian soinari of the size of the Megrelian larchemi.

According to the specimens and documentation available to us today, Georgian (Gurian and Megrelian) panpipes were usually made from six closed pipes. The longest two pipes are located in the center, the others - sideways according to length (figure 6).

\footnotetext{
${ }^{11}$ https://www.youtube.com/watch?v=3QrOpHbpF3w
} 


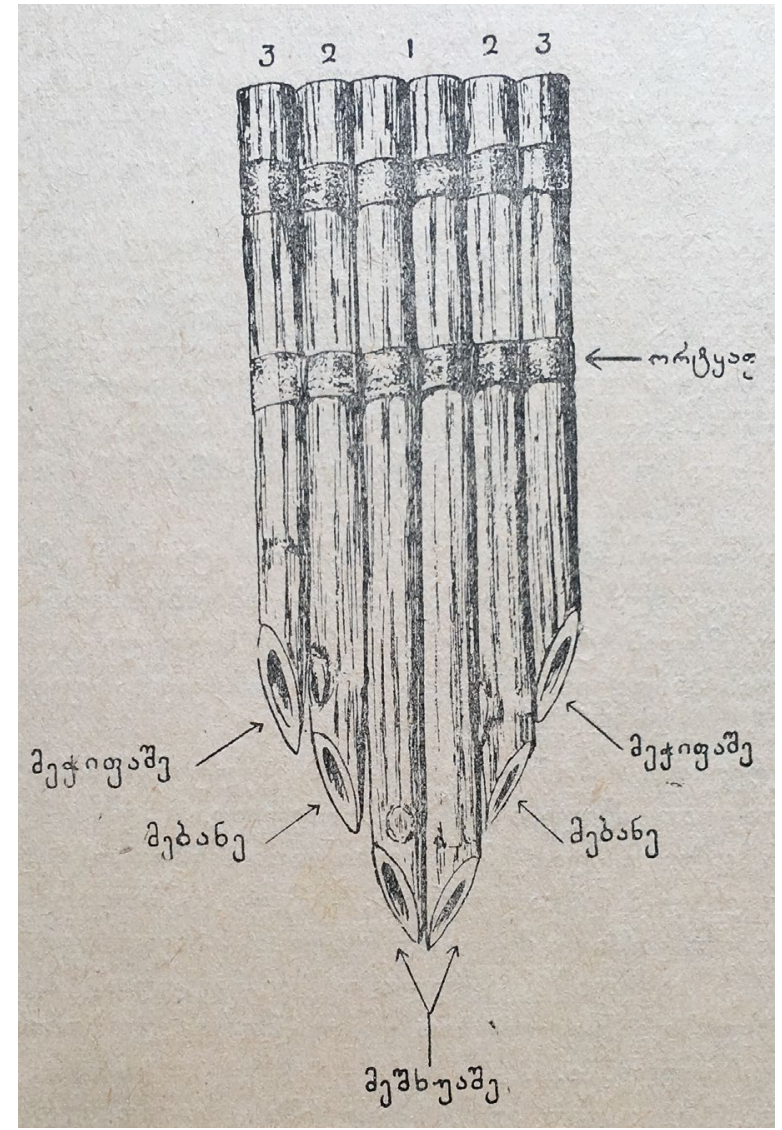

Figure 6. Six-pipe Georgian panpipe (Makalatia, 1941: 256)

V. Steshenko-Kuptina noted that the pipes of this construction could be a very rare, or perhaps, only kind of the panpipes disseminated throughout the world (SteshenkoKuptina, 1936: 208; Rosebashvili, 1960: 50-51).

According to S. Makalatia, a five-pipe panpipe was extant in Samegrelo (in Khobi). Unlike six-pipe instruments, this one had pipes located next to each other in order of length (figure7). Unfortunately, we have no information about its tuning or repertoire (Makalatia, 1941: 255-259). 


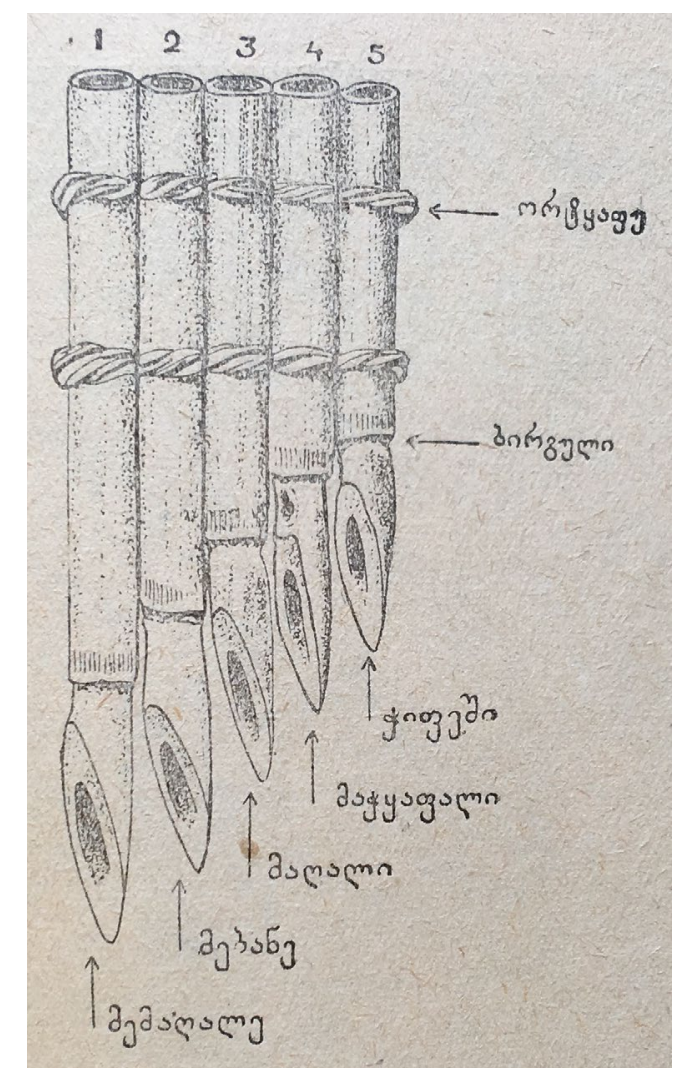

Figure 7. Five-pipe Georgian panpipe (Makalatia, 1941: 257)

Interestingly, sometimes when playing Megrelian repertoire on six-pipe larchemi, performers use only five out of the six pipes. Names of the pipes of Georgian panpipes, whether there are five or six pipes present, are somewhat similar, and the pitches and functions of the $1^{\text {st }}, 2^{\text {nd }}, 3^{\text {rd }}, 4^{\text {th }}$ and $5^{\text {th }}$ pipes on the five-pipe flute correspond to those of the $4^{\text {th }}, 3^{\text {rd }}, 5^{\text {th }}, 2^{\text {nd }}$ and $1^{\text {st }}$ pipes on the six-pipe flute.

V. Steshenko-Kuptina found some indication of the presence of instruments with seven and twelve pipes existing at some point in Lazeti, although she could not prove it with any certainty (Steshenko-Kuptina, 1936: 183).

\section{Names of pipes in Samegrelo and Guria}

Different researchers have recorded the names of the pipes of the Megrelian larchemi and Gurian soinari, which sometimes significant differ from each other (tables 1 and 2). 
Table 1. Pipe names of Megrelian larchemi

\begin{tabular}{|c|c|c|c|c|c|c|c|c|c|c|c|}
\hline & \multicolumn{3}{|c|}{ Steshenko-Kuptina } & \multicolumn{2}{|r|}{ Makalatia } & \multicolumn{4}{|c|}{ Rosebashvili } & \multicolumn{2}{|l|}{ Kobalia } \\
\hline 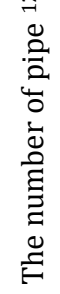 & 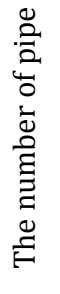 & \multicolumn{2}{|c|}{ Name } & 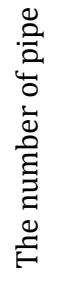 & Name & 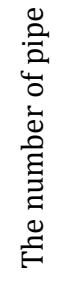 & \multicolumn{2}{|l|}{ Name } & 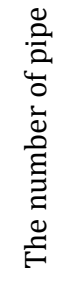 & \multicolumn{2}{|l|}{ Name } \\
\hline 1 & 6 & mechipashe & \multirow[b]{3}{*}{$\begin{array}{c}\text { ukulashi } \\
\text { (smaller), } \\
\text { left side }\end{array}$} & 3 & mechipashe & 1 & mechipane & \multirow[b]{3}{*}{$\begin{array}{l}\text { Right } \\
\text { side }\end{array}$} & [6] & gumorduli & \multirow[b]{3}{*}{ 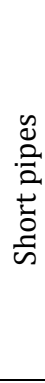 } \\
\hline 2 & 4 & gemachkapali & & 2 & mebane (bass) & [2] & mebane, bani (bass) & & [4] & $\begin{array}{l}\text { mechipe, } \\
\text { mechipeshi }\end{array}$ & \\
\hline 3 & 2 & $\begin{array}{c}\text { mebane } \\
\text { (maghali bani } \\
\text { (high bass), } \\
\text { mtavari bani } \\
\text { (main bass), } \\
\text { didi bani } \\
\text { (great bass) }\end{array}$ & & 1 & meshkhuashe & 3 & $\begin{array}{l}\text { meshkhuashe, } \\
\text { Gemachkapali } \\
\text { (beginner) }\end{array}$ & & 2 & $\begin{array}{l}\text { mebane, } \\
\text { chipeshi, } \\
\text { chipebanishi }\end{array}$ & \\
\hline 4 & 1 & $\begin{array}{c}\text { mebane } \\
\text { (meore bani } \\
\text { (second bass), } \\
\text { patara bani } \\
\text { (small bass) }\end{array}$ & \multirow{3}{*}{$\begin{array}{l}\text { umosi } \\
\text { (bigger), } \\
\text { right side }\end{array}$} & 1 & meshkhuashe & [4] & $\begin{array}{l}\text { meshkhuashe, } \\
\text { gemachkapali }\end{array}$ & \multirow{3}{*}{$\begin{array}{l}\text { umosi } \\
\text { (bigger), } \\
\text { left side }\end{array}$} & 1 & $\begin{array}{l}\text { mebane, } \\
\text { shkhushi, } \\
\text { shkhubanishi }\end{array}$ & \multirow{3}{*}{ 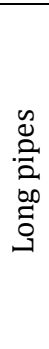 } \\
\hline 5 & 3 & $\begin{array}{l}\text { gemachkapali, } \\
\text { gemachkapuri } \\
\text { (beginner) }\end{array}$ & & 2 & mebane (bass) & [5] & mebane, bani (bass) & & [3] & $\begin{array}{l}\text { gochipeshi, } \\
\text { gopsha }\end{array}$ & \\
\hline 6 & 5 & mechipashe & & 3 & mechipashe & [6] & mechipane & & [5] & gemachkepuri & \\
\hline
\end{tabular}

Table 2. Pipe names of Gurian soinari

\begin{tabular}{|c|c|c|c|c|c|c|c|c|}
\hline & \multicolumn{3}{|c|}{ Steshenko-Kuptina, 1} & \multicolumn{2}{|c|}{ Steshenko-Kuptina, 2} & \multicolumn{3}{|c|}{ Rosebashvili } \\
\hline 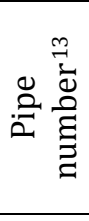 & 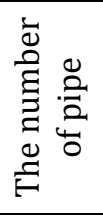 & Nam & & 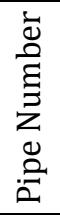 & Name & 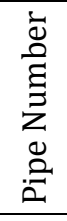 & Name & \\
\hline 1 & 6 & Sixth voice & \multirow{3}{*}{$\begin{array}{l}\text { Left } \\
\text { side }\end{array}$} & 6 & $\begin{array}{l}\text { modzakhili, } \\
\text { krimanchuli }\end{array}$ & [1] & krimanchuli & \multirow{3}{*}{$\begin{array}{l}\text { Right } \\
\text { side }\end{array}$} \\
\hline 2 & 4 & Fourth voice & & 4 & gadatanili & 2 & High bass & \\
\hline 3 & 2 & Small bass & & 2 & sashualo & 3 & Low bass & \\
\hline 4 & 1 & Great bass & \multirow{3}{*}{$\begin{array}{l}\text { Right } \\
\text { side }\end{array}$} & 1 & bani (bass) & 3 & Bass & \multirow{3}{*}{$\begin{array}{l}\text { Left } \\
\text { side }\end{array}$} \\
\hline 5 & 3 & Third voice & & 3 & tskeba & 2 & Second voice & \\
\hline 6 & 5 & Fifth voice & & 5 & modzakhili & [1] & krimanchuli & \\
\hline
\end{tabular}

12 Numbered by the author (N.R.).

${ }^{13}$ Numbered by the author (N.R.). 
According to different researchers, bass pipes, which are the longest, were sometimes located in the middle, and sometimes second and forth in the row, next to the middle pipes. In the repertoire available to us, the bass function is allocated to the $3^{\text {rd }}$ and $4^{\text {th }}$ pipes, not the $5^{\text {th }}$ or $2^{\text {nd }}$. I think there is a mistake in Makalatia's records, repeated by K. Rosebashvili and 0. Chijavadze. Bass pipes are named as middle pipes by Rosebashvili in his research: "If we start counting from the middle or the bass pipe [...]" (Rosebashvili, 1960: 52).

\section{Numbering of pipes}

Understandably, different Georgian researchers number the pipes of the larchemi and soinari in different ways (tables 1 and 2). V. Steshenko-Kuptina numbers the pipes corresponding to their pitch, so that the longest pipe is \#1. In S. Makalatia's numbering system the larchemi is divided into two parts, and the numbering principle also depends on the pitch sequence of the pipes. A perception of the two parts of the instrument is evident in folk terminology as well, when the performers report to us the terms umosi and ukulashi (these terms are defined below). His numbering of the soinari pipes is different and, like S. Makalatia's numbering system, is based on the division of the instrument into two parts (3-3).

In fact, Steshenko-Kuptina, Makalatia and Kobalia deal with the numbering of pipes by starting from the longest and counting up towards the shortest, while by Rosebashvili starts from the shortest pipe, according to the layout. As for the five-pipe larchemi, in Makalatia's research the numbering starts from the longest pipe counting up towards the shortest one as well (tables 1 and 2).

According to popular international practice, each separate pipe of the panpipe is identified either with numbers or with the Latin symbols for the pitches. I have found two versions of numbering: in the first version, pipes are numbered according to their pitch, with the longest counted as \#1 (Civallero, 2014: 249); in the second, pipes with different pitches are numbered according to the sequence that corresponds to the tuning of the instrument (Civallero, 2014: 257).

When numbering the pipes, I have adopted the principle of K. Rosebashvili, to number the pipes strating with the shortest one in sequence. This is because numbering according to the sequence seems to be convenient for notation, and the analysis of the 
audio material has shown that performers usually used to play the shorter trio, rather than the long pipes. Furthermore, sometimes performers did not use the $6^{\text {th }}$ pipe.

Dividing the sides of the instrument into left and right sides was also approached differently by V. Steshenko-Kuptina/Arakishvili and Rosebashvili; For V. SteshenkoKuptina/Arakishvili the left side is ukulashi, but for Rosebashvili it is umosi (Megrelian: senior, long-piped). The first approach indicates the left and right sides from the point of view of the observer, while the second speaks from the position of the performer. In this case, I prefer the position of $\mathrm{K}$. Rosebashvili, because the right side probably was ukulashi for the performer.

\section{Performing Technique and Notation}

We have very little information about the features of traditional performance on the larchemi and soinari. Unfortunately, because there is no video documentation, there is no way to recapture some aspects of performance, although studying the tunings and the audio and score samples allow us to define some features.

Performers simultaneously blow the $6^{\text {th }}-5^{\text {th }}, 5^{\text {th }}-4^{\text {th }}, 3^{\text {rd }}-2^{\text {nd }}, 2^{\text {nd }}-1^{\text {st }}$ and $3^{\text {rd }}-2^{\text {nd }}-1^{\text {st }}$ pipes. They do not use $4^{\text {th }} 3^{\text {rd }}$ (bass) pipe combination. While using pipes sequentially, they mostly use side pipes. Long distance intervals are rare, for instance, from the $3^{\text {rd }}$ pipe to the $1^{\text {st }}$ and vice versa, or $1^{\text {st }}-2^{\text {nd }}$ pipe to the $5^{\text {th }}-6^{\text {th }}$ ones.

In the samples of 'Nirzi'14, the performers sequentially blow pipes (one each) located side by side (for example: 2123232321232... Steshenko-Kuptina, 1936: 275), or one performer blows two adjacent pipes and the other blows each of the adjacent pipes (audio instrumental piece, \# $\underline{22}$ ). In other words, for the most part, performers, actually, blow the neighbouring pipes. Blowing the outer pipes and skipping the middle one is

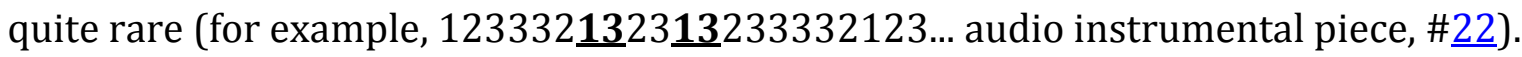

As the musical analysis shows, the performers on the recordings from the 1930s were intensively mastering all of the six pipes, while in the recordings from the1950s they were using 5 pipes out of 6 . In both sets of recordings the side of the instrument with the short pipes is more actively used by performers.

${ }^{14}$ A musical competition where two performers play the same instrument by dividing pipes, three each, described in detail below. 
Playing intervals and chords can be achieved by blowing pipes simultaneously, as well as separately. Each pipe produces one pitch; the pitch does not shift by raising and lowering the pipe end, or by changing the sound length.

Steshenko-Kuptina notes that there is a very remarkable way of playing the panpipe: performers press their lips tightly against gaps between the pipes, blowing into two pipes simultaneously so that the interval of a third is played. Getting equally full and precise sounds from both pipes is dependent on the performer's breath technique (1936: 208-209). This technique of playing the six-pipe salamuri was not shown in the audio recordings. It is worth noting that because of the different construction, in order to perform the repertoire available to us, a five-pipe larchemi would be necessary- there are many intervals of a third, so closing the middle pipe would be closed using one's tongue.

M. Shilakadze noted that the design and construction of the instrument was related to the tradition of polyphonic performance (Shilakadze, 1970: 70). Indeed, the aforementioned performance manner is quite uncomfortable to create polyphony, and maybe, getting this kind of sound with a less complicated playing technique became the prerequisite for making the instrument with an original construction. It is worth noting that the Ecuadorian rondador, the only one of the world's panpipes I have found on which two-voice music is played, also has an unusual construction ${ }^{15}$. In different cultures (Peru, Russia, etc.) polyphony is achieved in ensemble performance, when several performers play simultaneously.

It is difficult to know which side of the instrument was considered the right side from the perspective of the performer without video sources. Also, if we take the sequence of the pipes into consideration, when showing the tuning of the instrument, supposedly, the side named umosi (named by Steshenko-Kuptina) would be the left side.

Notated sources are provided in the works by Steshenko-Kuptina and Rosebashvili; the former researcher uses optional notes for some features (score example 1), while the latter does not. Taking the international practice into consideration, I think that marking

15 I would like to thank researchers Edgardo Civallero and Rūta Šimonytė-Žarskienè for information and consultation. 
the pipes with numbers provides crucial information, and thus I do this in my own notation examples.

a)

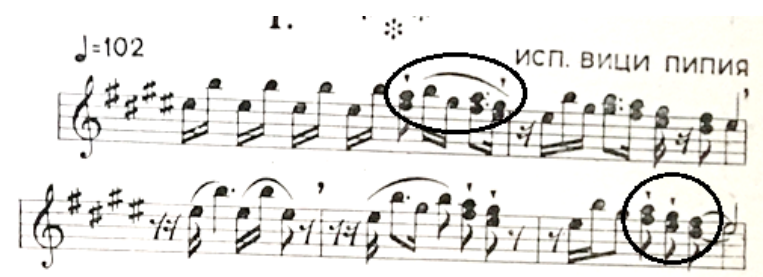

b)

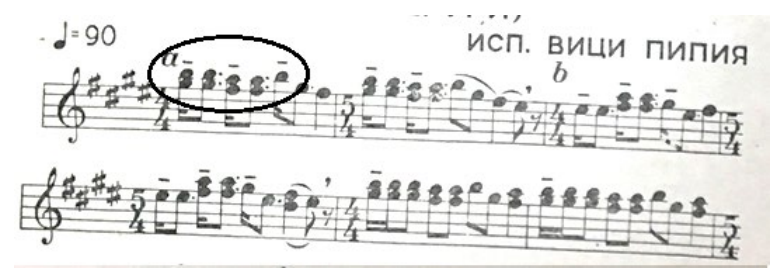

c)

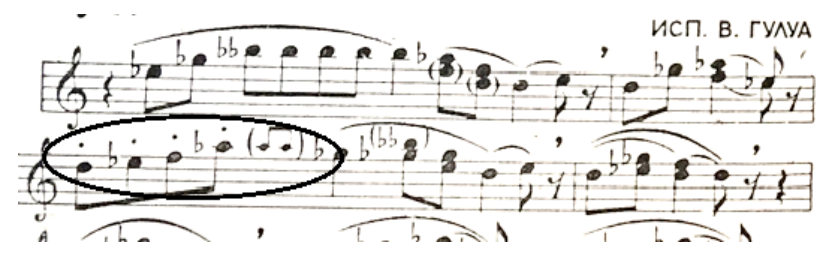

Score example 1. Notated sources with optional notes (Steshenko-Kuptina, 1936: 273, 274, 276).

\section{Tuning}

In the audio and notated sources of the Georgian panpipe available to us, 21 tunings are recorded. There are nine notated tunings of the larchemi (score example 2: 1-9) and three of the soinari (score example 4: 10-12), though in audio recordings there are four tunings of the larchemi (audio examples $\underline{8}, \underline{14}, \underline{18}, \underline{22}$ ) and three of the soinari (audio examples $\underline{1} \underline{5}, \underline{25}$ ). Also, there are other tunings for each instrument that are not recorded separately, although they are evident from the playing (audio examples $\underline{7}, \underline{30}$ ). 

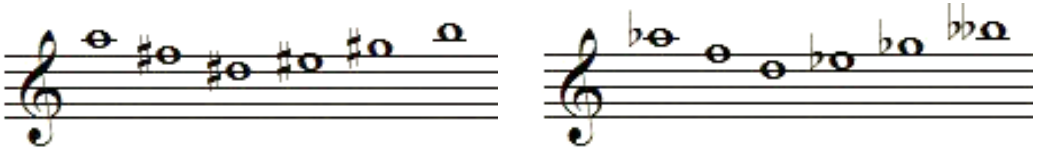

2.2.b. Steshenko-Kuptina, 1936: 275

2.3. Steshenko-Kuptina, 1936: 276
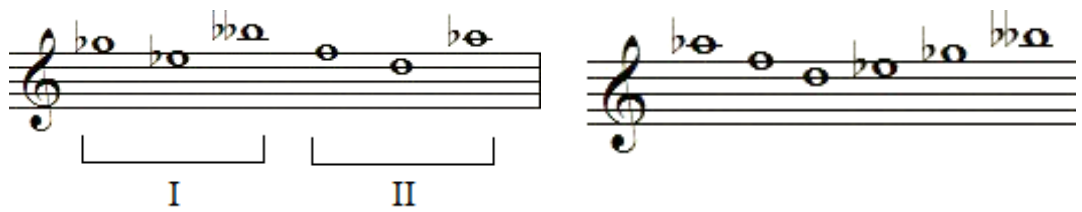

2.4. Rosebashvili, 1975, 1981: 45

2.5. Rosebashvili, 1986: 2
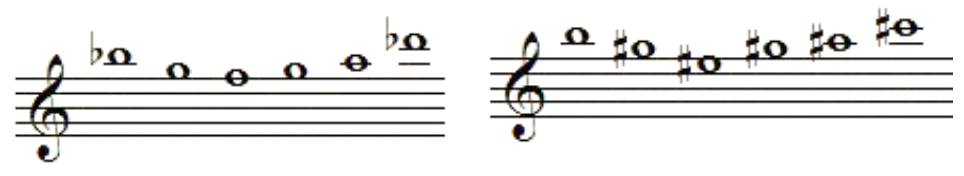

2.6. Rosebashvili, 1975, 1986: 3

2.7. Rosebashvili, 1975, 1981: 45
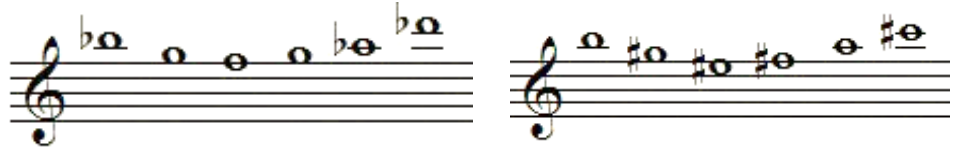

2.8. Rosebashvili, 1981: 45

2.9. Rosebashvili, 1981: 45
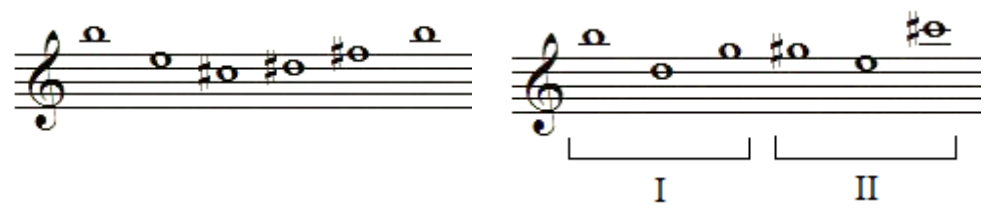

2.10. Steshenko-Kuptina, 1936: 278

2.11. Rosebashvili, 1985 : $[1,5]$
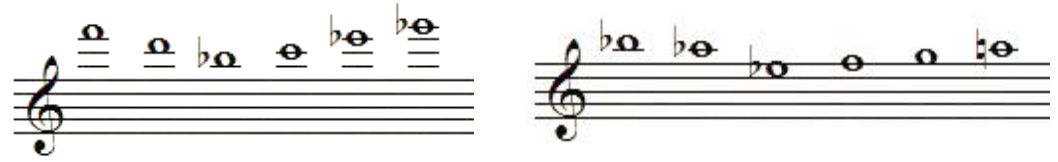

2.12. Rosebashvili, 1985: [3]

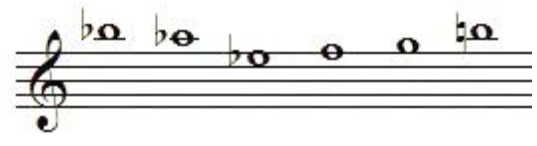

Score example 2. Tunings of larchemis and soinaris 
I aim to determine the interaction of these tunings, to make corrections in notated tunings based on the analysis of audio sources if necessary, and to identify technical flaws in the notated tunings that reduce the number of notated tunings. While determining, identifying and notating the tunings the main basis is the principles of tuning provided by Steshenko-Kuptina.

\section{Analyzing frequencies}

Steshenko-Kuptina transferred each note to a monochord string tuned according to a tuning fork, to measure the frequencies of the larchemi and soinari. She considered this method to be more objective than measuring it with a wind instrument (SteshenkoKuptina, 1936: 226). In that way she measured the pitches of the pipes of five tuned instruments in hertz (Steshenko-Kuptina, 1936: 167, 168, 226; Table 3: 1-4).

Table 3. Analyzing frequencies of larchemis and soinaris (Стешенко-Куфтіна, 1936: 167)

3.1. I larchemi

\begin{tabular}{|c|c|c|c|c|c|c|}
\hline & $6^{\text {th }}$ pipe & $5^{\text {th }}$ pipe & $4^{\text {th }}$ pipe & $3^{\text {rd }}$ pipe & $2^{\text {nd }}$ pipe & $1^{\text {st }}$ pipe \\
\hline Hertz & 903 & 734 & 613 & 701 & 830 & 1008 \\
\hline Cent & $-358,735$ & $-311,872$ & 232,2328 & 292 & 336,3749 \\
\hline & A & Fis & Dis & Eis & Gis & H \\
\hline
\end{tabular}

3.2. II larchemi

\begin{tabular}{|c|c|c|c|c|c|c|}
\hline & $6^{\text {th }}$ pipe & $5^{\text {th }}$ pipe & $4^{\text {th }}$ pipe & $3^{\text {rd }}$ pipe & $2^{\text {nd }}$ pipe & $1^{\text {st }}$ pipe \\
\hline Hertz & 839 & 701 & 580 & 631 & 746 & 896 \\
\hline Cent & $-311,108$ & $-328,034$ & 145,9045 & 290 & 317,1877 \\
\hline & A & Fis & Dis & Eis & Gis & H \\
\hline
\end{tabular}

3.3. III larchemi

\begin{tabular}{|c|c|c|c|c|c|c|}
\hline & $6^{\text {th }}$ pipe & $5^{\text {th }}$ pipe & $4^{\text {th }}$ pipe & $3^{\text {rd }}$ pipe & $2^{\text {nd }}$ pipe & $1^{\text {st }}$ pipe \\
\hline Hertz & 863 & 716 & 583 & 606 & 739 & 903 \\
\hline Cent & $-323,281$ & $-355,756$ & \begin{tabular}{l|l}
756 & 66 \\
\end{tabular} & 66,98629 & \multicolumn{2}{|c|}{346,9819} \\
\hline & A & Fis & Dis & Eis & Gis & $\mathrm{H}$ \\
\hline
\end{tabular}

3.4. Soinari

\begin{tabular}{|c|c|c|c|c|c|c|c|}
\hline & $6^{\text {th }}$ pipe & $5^{\text {th }}$ pipe & \multicolumn{2}{c|}{$4^{\text {th }}$ pipe } & $3^{\text {rd }}$ pipe & $2^{\text {nd }}$ pipe & $1^{\text {st }}$ pipe \\
\hline Hertz & 1398 & \multicolumn{2}{|c|}{1217} & 970 & 1069 & 1290 & 1496 \\
\hline Cent & $-240,042$ & $-392,727$ & 168,2462 & 325,3311 & 357,337 \\
\hline & F & D & B & C & Es & Ges \\
\hline
\end{tabular}


I have measured audio samples of tunings and repertoire of five larchemis and five soinaris in the program Adobe Audition ${ }^{16}$. For some notes I chose different enharmonic variants depending on which note would be relevant to the tuning principle of $\mathrm{V}$. Steshenko-Kuptina. Based on the hertz measured by me and determined by SteshenkoKuptina, I calculated the distance between notes (in cents) for each tuning, with the pitch sequences and scales set out in Table 4 .

Table 4. Analyzing frequencies of larchemis and soinaris

\begin{tabular}{|c|c|c|c|c|c|c|c|c|c|c|c|c|}
\hline & \multicolumn{2}{|c|}{$6^{\text {th }}$ pipe } & \multicolumn{2}{|c|}{$5^{\text {th }}$ pipe } & \multicolumn{2}{|c|}{$4^{\text {th }}$ pipe } & \multicolumn{2}{|c|}{$3^{\text {rd }}$ pipe } & \multicolumn{2}{|c|}{$2^{\text {nd }}$ pipe } & \multicolumn{2}{|c|}{$1^{\text {st }}$ pipe } \\
\hline $\begin{array}{l}\text { I Larchemi } \\
\text { (audio ex. } \underline{8} \text { ) }\end{array}$ & $\begin{array}{c}860 \\
\text { Hertz }\end{array}$ & $\begin{array}{c}\text { A5 } \\
-25 \\
\text { cents } \\
\end{array}$ & $\begin{array}{c}719 \\
\text { Hertz }\end{array}$ & $\begin{array}{c}\text { F\#5 } \\
-49 \\
\text { cents } \\
\end{array}$ & $\begin{array}{c}625 \\
\text { Hertz }\end{array}$ & $\begin{array}{c}\text { D\#5 +7 } \\
\text { cents }\end{array}$ & $\begin{array}{c}715 \\
\text { Hertz }\end{array}$ & $\begin{array}{c}\text { F5 } \\
+41 \\
\text { cents } \\
\end{array}$ & $\begin{array}{l}806 \\
\text { Hertz }\end{array}$ & $\begin{array}{c}\text { Ab5 } \\
-47 \\
\text { cents } \\
\end{array}$ & $\begin{array}{l}1020 \\
\text { Hertz }\end{array}$ & $\begin{array}{c}\text { C6 } \\
-20 \\
\text { cents } \\
\end{array}$ \\
\hline $\begin{array}{c}\text { II Larchemi } \\
\text { (audio ex. } \\
\underline{14} \text { ) } \\
\end{array}$ & $\begin{array}{c}880 \\
\text { Hertz }\end{array}$ & A5 & $\begin{array}{c}760 \\
\text { Hertz }\end{array}$ & $\begin{array}{c}\text { G5 } \\
-55 \\
\text { cents } \\
\end{array}$ & $\begin{array}{c}647 \\
\text { Hertz }\end{array}$ & $\begin{array}{c}\text { E5 } \\
-30 \\
\text { cents } \\
\end{array}$ & $\begin{array}{c}740 \\
\text { Hertz }\end{array}$ & $\begin{array}{c}\text { F\#5 } \\
+1 \\
\text { cents } \\
\end{array}$ & $\begin{array}{l}850 \\
\text { Hertz }\end{array}$ & $\begin{array}{c}\text { A5 } \\
-60 \\
\text { cents } \\
\end{array}$ & 993 Hertz & $\begin{array}{c}\text { Ces5 } \\
+10 \\
\text { cents } \\
\end{array}$ \\
\hline $\begin{array}{l}\text { III Larchemi } \\
\text { (audio ex. } \\
\text { 18) }\end{array}$ & $\begin{array}{c}883 \\
\text { Hertz }\end{array}$ & $\begin{array}{l}\text { A5 }+5 \\
\text { cents }\end{array}$ & $\begin{array}{c}580 \\
\text { Hertz }\end{array}$ & $\begin{array}{c}\text { D5 } \\
-21 \\
\text { cents }\end{array}$ & $\begin{array}{c}495 \\
\text { Hertz }\end{array}$ & $\begin{array}{c}\mathrm{H} 4 \\
+5 \\
\text { cents }\end{array}$ & $\begin{array}{c}554 \\
\text { Hertz }\end{array}$ & $\begin{array}{l}\text { C\#5 -1 } \\
\text { cents }\end{array}$ & $\begin{array}{c}677 \\
\text { Hertz }\end{array}$ & $\begin{array}{c}\text { E5 }+47 \\
\text { cents }\end{array}$ & 876 Hertz & $\begin{array}{c}\text { A5 } \\
-7 \\
\text { cents }\end{array}$ \\
\hline $\begin{array}{c}\text { IV Larchemi } \\
\text { (audio ex. } \\
\underline{22} \text { ) }\end{array}$ & $\begin{array}{c}890 \\
\text { Hertz }\end{array}$ & $\begin{array}{c}\text { A5 } \\
+21 \\
\text { cents } \\
\end{array}$ & $\begin{array}{c}699 \\
\text { Hertz }\end{array}$ & $\begin{array}{l}\text { F5 +2 } \\
\text { cents }\end{array}$ & $\begin{array}{c}540 \\
\text { Hertz }\end{array}$ & $\begin{array}{l}\text { C5 }+55 \\
\text { cents }\end{array}$ & $\begin{array}{c}692 \\
\text { Hertz }\end{array}$ & $\begin{array}{c}\text { D5 } \\
+15 \\
\text { cents } \\
\end{array}$ & $\begin{array}{c}741 \\
\text { Hertz }\end{array}$ & $\begin{array}{c}\text { F\#5 } \\
+2 \\
\text { cents } \\
\end{array}$ & 971 Hertz & $\begin{array}{c}\text { H5 } \\
-29 \\
\text { cents } \\
\end{array}$ \\
\hline $\begin{array}{c}\text { V Larchemi } \\
\text { (audio ex. } \\
\underline{\underline{30}} \text { ) }\end{array}$ & & & $\begin{array}{c}747,71 \\
\text { Hertz }\end{array}$ & $\begin{array}{c}\text { F\#5 } \\
+17 \\
\text { cents } \\
\end{array}$ & $\begin{array}{c}630,65 \\
\text { Hertz }\end{array}$ & $\begin{array}{c}\text { D\#5 } \\
+23 \\
\text { cents } \\
\end{array}$ & $\begin{array}{l}708,3 \\
\text { Hertz }\end{array}$ & $\begin{array}{c}\mathrm{F} 5+24 \\
\text { cents }\end{array}$ & $\begin{array}{c}808,39 \\
\text { Hertz }\end{array}$ & $\begin{array}{c}\text { G\#5 - } \\
46 \\
\text { cents } \\
\end{array}$ & $\begin{array}{c}993,82 \\
\text { Hertz }\end{array}$ & $\begin{array}{c}\text { H5 } \\
+10 \\
\text { cents } \\
\end{array}$ \\
\hline $\begin{array}{c}\text { I Soinari } \\
\text { (audio ex. } 1 \text { ) }\end{array}$ & $\begin{array}{l}1343 \\
\text { Hertz }\end{array}$ & $\begin{array}{c}\text { E6 }+33 \\
\text { cents }\end{array}$ & $\begin{array}{l}1150 \\
\text { Hertz }\end{array}$ & $\begin{array}{c}\text { D6 } \\
-36 \\
\text { cents } \\
\end{array}$ & $\begin{array}{c}948 \\
\text { Hertz }\end{array}$ & $\begin{array}{c}\text { B5 }+28 \\
\text { cents }\end{array}$ & $\begin{array}{l}1051 \\
\text { Hertz }\end{array}$ & $\begin{array}{c}\text { C6 } \\
-11 \\
\text { cents } \\
\end{array}$ & $\begin{array}{l}1279 \\
\text { Hertz }\end{array}$ & $\begin{array}{c}\mathrm{Eb} \\
-7 \\
\text { cents }\end{array}$ & $\begin{array}{l}1479 \\
\text { Hertz }\end{array}$ & $\begin{array}{c}\mathrm{Gb} \\
-0 \\
\text { cents } \\
\end{array}$ \\
\hline $\begin{array}{c}\text { II Soinari } \\
\text { (audio ex. } \underline{5} \text { ) }\end{array}$ & $\begin{array}{l}1014 \\
\text { Hertz }\end{array}$ & $\begin{array}{c}\text { H5 } \\
+45 \\
\text { cents } \\
\end{array}$ & $\begin{array}{c}854 \\
\text { Hertz }\end{array}$ & $\begin{array}{c}\text { Ab5 } \\
+48 \\
\text { cents } \\
\end{array}$ & $\begin{array}{c}699 \\
\text { Hertz }\end{array}$ & $\begin{array}{c}\text { F5 } \\
+2 \\
\text { cents } \\
\end{array}$ & $\begin{array}{c}770 \\
\text { Hertz }\end{array}$ & $\begin{array}{c}\text { G5 } \\
-30 \\
\text { cents } \\
\end{array}$ & $\begin{array}{l}996 \\
\text { Hertz }\end{array}$ & $\begin{array}{c}\text { H5 } \\
-36 \\
\text { cents } \\
\end{array}$ & $\begin{array}{c}\text { 1151,11 } \\
\text { Hertz }\end{array}$ & $\begin{array}{c}\text { D6 } \\
-35 \\
\text { cents } \\
\end{array}$ \\
\hline $\begin{array}{c}\text { III Soinari } \\
\text { (audio ex. } \underline{7} \text { ) }\end{array}$ & $\begin{array}{c}936 \\
\text { Hertz }\end{array}$ & $\begin{array}{l}\text { B5 +6 } \\
\text { cents }\end{array}$ & $\begin{array}{c}735 \\
\text { Hertz }\end{array}$ & $\begin{array}{c}\text { Gb5 } \\
-10 \\
\text { cents } \\
\end{array}$ & $\begin{array}{c}630 \\
\text { Hertz }\end{array}$ & $\begin{array}{c}\text { Eb5 } \\
+22 \\
\text { cents } \\
\end{array}$ & $\begin{array}{c}699 \\
\text { Hertz }\end{array}$ & $\begin{array}{l}\text { F5 +2 } \\
\text { cents }\end{array}$ & $\begin{array}{c}814 \\
\text { Hertz }\end{array}$ & $\begin{array}{c}\text { Ab5 } \\
-32 \\
\text { cents } \\
\end{array}$ & 964 Hertz & $\begin{array}{c}\text { Cb5 } \\
-41 \\
\text { cents } \\
\end{array}$ \\
\hline $\begin{array}{l}\text { IV Soinari } \\
\text { (audio ex. } \\
\underline{25} \text { ) }\end{array}$ & $\begin{array}{c}932 \\
\text { Hertz }\end{array}$ & $\begin{array}{l}\text { B5 +0 } \\
\text { cents }\end{array}$ & $\begin{array}{c}822 \\
\text { Hertz }\end{array}$ & $\begin{array}{c}\text { Ab5 } \\
-16 \\
\text { cents } \\
\end{array}$ & $\begin{array}{c}633 \\
\text { Hertz }\end{array}$ & $\begin{array}{c}\text { Eb5 } \\
+30 \\
\text { cents }\end{array}$ & $\begin{array}{c}698 \\
\text { Hertz }\end{array}$ & $\begin{array}{c}\text { F5 } \\
-0 \\
\text { cents } \\
\end{array}$ & $\begin{array}{c}779 \\
\text { Hertz }\end{array}$ & $\begin{array}{c}\text { G5 } \\
-9 \\
\text { cents }\end{array}$ & 875 Hertz & $\begin{array}{c}\text { A5 } \\
-8 \\
\text { cents } \\
\end{array}$ \\
\hline $\begin{array}{l}\text { V Soinari } \\
\text { (audio ex. } \\
\underline{32} \text { ) }\end{array}$ & $\begin{array}{l}1398 \\
\text { Hertz }\end{array}$ & $\begin{array}{c}\mathrm{F} \\
+1 \\
\text { cents }\end{array}$ & $\begin{array}{l}1217 \\
\text { Hertz }\end{array}$ & $\begin{array}{l}D+61 \\
\text { cents }\end{array}$ & $\begin{array}{c}970 \\
\text { Hertz }\end{array}$ & $\begin{array}{l}B+68 \\
\text { cents }\end{array}$ & $\begin{array}{l}1069 \\
\text { Hertz }\end{array}$ & $\begin{array}{l}\mathrm{C}+36 \\
\text { cents }\end{array}$ & $\begin{array}{l}1290 \\
\text { Hertz }\end{array}$ & $\begin{array}{c}E b \\
+62 \\
\text { cents }\end{array}$ & $\begin{array}{l}1496 \\
\text { Hertz }\end{array}$ & $\begin{array}{c}\mathrm{Gb} \\
+18 \\
\text { cents }\end{array}$ \\
\hline
\end{tabular}

16 I am grateful to Levan Veshapidze and Ilia Jgharkava for teaching me the methodology of measuring hertz and cents and for consultating me as I worked. 


\section{Tuning the instrument}

Stesheko-Kuptina recorded the technique of the tuning process for the soinari: "the great bass is thought to be the principal tone, from which they find the minor bass at a distance of about 3/417 tones. From both of the basses they find both thirds. When assessing the tuning, they use two corrective methods: the first bass and the right third 18 and the second bass with the left third ${ }^{19}$; then they assess the first, second, third, fourth, fifth and sixth voices" (Steshenko-Kuptina, 1936: 212). Stesheko-Kuptina is of the opinion that the West Georgian panpipe has such clear tuning and firm principles of tuning that we can consider it as a musical system (Steshenko-Kuptina, 1936: 224). She recorded the method used for assessing and defining the tunings - stuffing the pipes with sand or corn flour (Steshenko-Kuptina, 1936: 208).

Steshenko-Kuptina herself was guided by the principles of tuning and notation mentioned above. She notated the tunings and the repertoire by preferring the aural impression and selecting an enharmonic version for the sounds ${ }^{20}$. Sometimes, the hertz values and notes selected by her do not match. For instance, each of the 'thirds played on the bass pipe' is provided by the researcher in every notated sample (score example 2: $1-3,10)$, although, according to her hertz analysis, when playing the outer pipes sequentially, the thirds do not always occur. If in the tempered tuning the distances between minor thirds are 300 cents, here, the distance between the notes varies from 240 to 360 cents. For instance, using the main principles of the instrument tuning: if the distance between the $6^{\text {th }}$ and $5^{\text {th }}$ pipes was 240 cents (table 3: 4), which causes it to sound closer to a major second (audio example $\underline{32}, \underline{40}$ ), she still records it as the notes $\mathrm{F}$ and D; this way she also takes her aural impression into consideration, because these two pipes sound to her close to a minor third apart (audio example $\underline{34} \underline{41}^{21}$ ). It was these 'differences' Steshenko-Kuptina was referring to when noting that in process of tuning of larchemi and soinari performers were using aural criteria that sometimes caused fluctuation and deviation.

\footnotetext{
17 In other words, 150 cents in tempered tuning.

18 The researcher implies third produced by pipes 4,5 and 6 .

19 The researcher implies pipe 3 and third produced by pipes 2 and 1 .

${ }^{20}$ For instance, if it is possible to record the note of 1217 herz as Es (-38 cents), she recorded as D (+62 cents).

${ }^{21}$ In the audio example 41, the last interval sounds as the third, repeated several times.
} 
In the 1950s, Rosebashvili's point of view about the firmness of the tuning, compared to that of Steshenko-Kuptina, seems less definitive. According to his observations, the interval sizes between the pipes depend on musical taste of the performer and the maker of the instrument, and also on the skill level of the performer - what intervals or sound combinations they want to create in the pieces they play. Such a free approach to the tuning of the instrument is not otherwise known to us, so it seems doubtful perhaps it is the impression of the researcher, or just a story from an informant. In Rosebashvili's audio recordings and scores we encounter second and fourth intervals that in my opinion are related to faulty instrument tuning and construction.

\section{Larchemi and soinari tunings}

Fieldwork expedition sources recorded by K. Rosebashvili and O. Chijavadze have historical importance, although in the research by K. Rosebashvili there are some flaws, especially in terms of tuning and of notating the repertoire.

While the tuning notations of the larchemi by Steshenko-Kuptina are always similar (although sometimes there is a major second between the fourth and third pipes, sometimes a minor second), the recordings by K. Rosebashvili are quite different. He recorded audio samples of five tunings (four larchemis and one soinari), but in the notated versions of these recordings there are seven tunings (six on larchemi and one on soinari). My research has led me to the following conclusions. Firstly, none of the notated repertoires matches precisely its recorded audio version. Secondly, it looks from the tunings of the four pieces recorded from Dzokia Aronia as if the performer plays four different instruments, but from the audio recordings we can verify that he used only two different instruments (score example 3: 1-4). Thirdly, sometimes the notated sample does not match the indicated tuning. Three out of four tunings match neither his audio recordings, nor the repertoire notated by him. Thus, musical analysis based on Rosebashvili's notated samples gave us faulty conclusions, both in Rosebashvili's own work, and in general. 


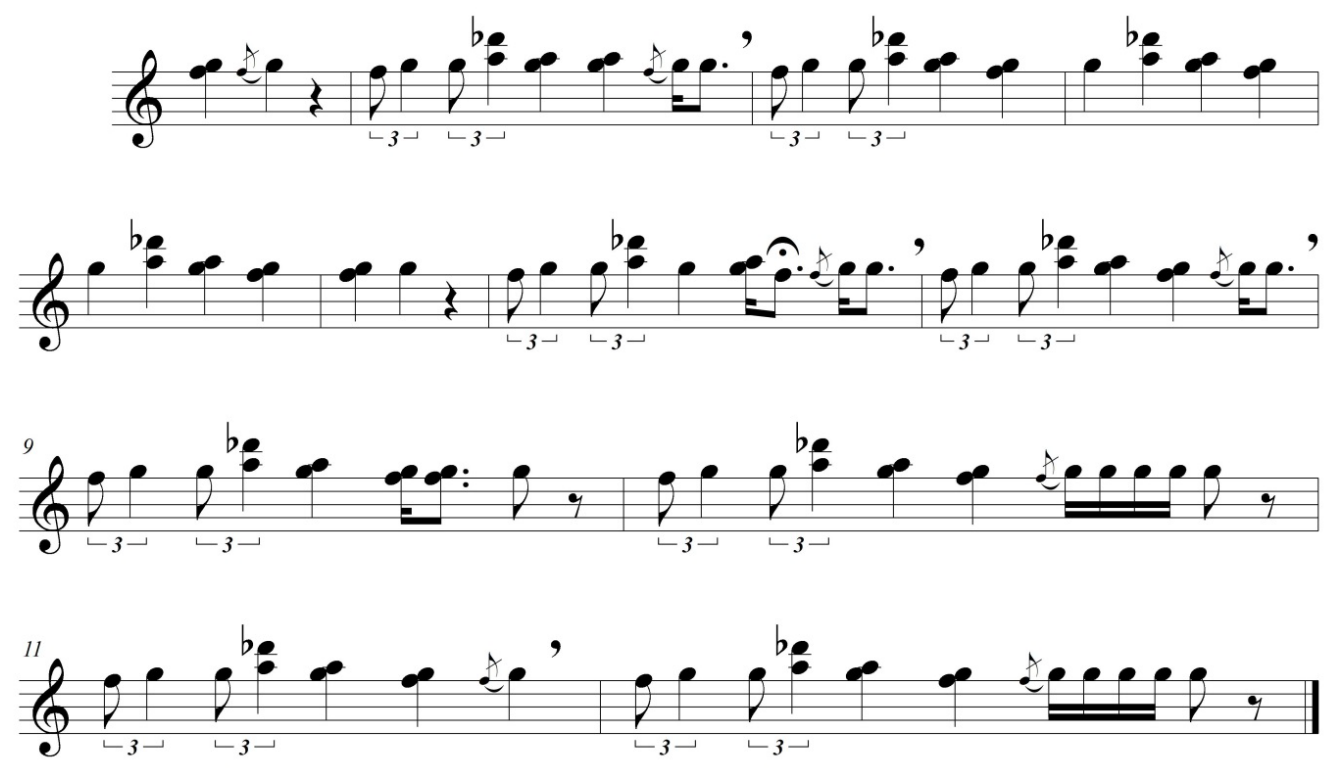

Score example 3.1. See the list of the notated instrumental pieces, \#11. Musical ex. \#10.
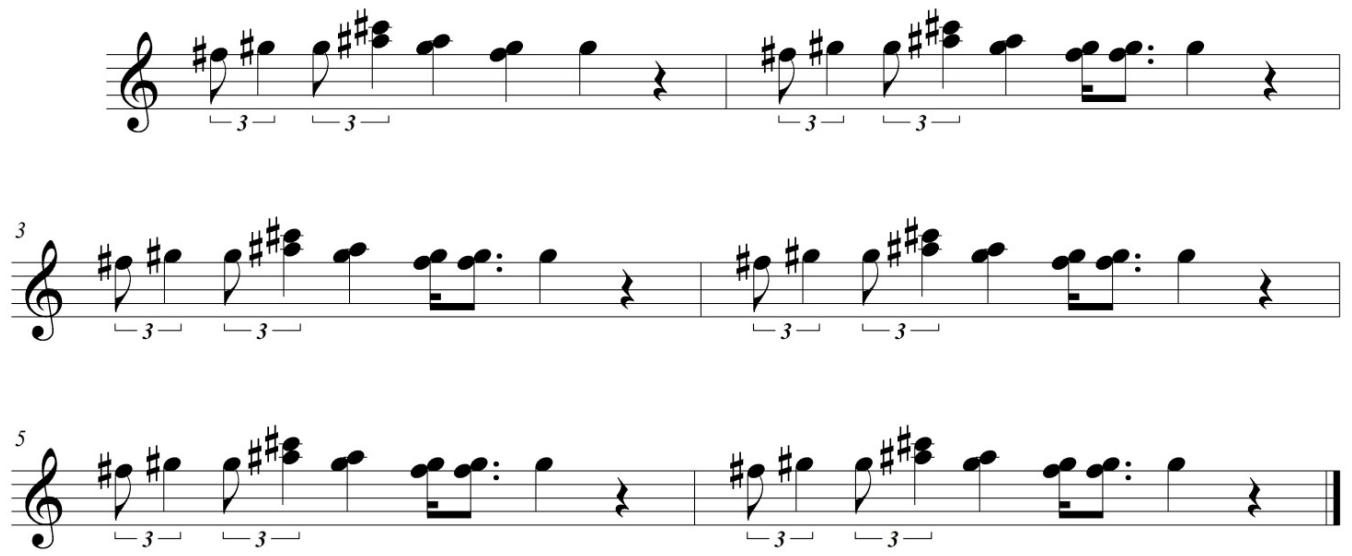

Score example 3.2. See the list of the notated instrumental pieces, \#12. Musical ex. \#16.

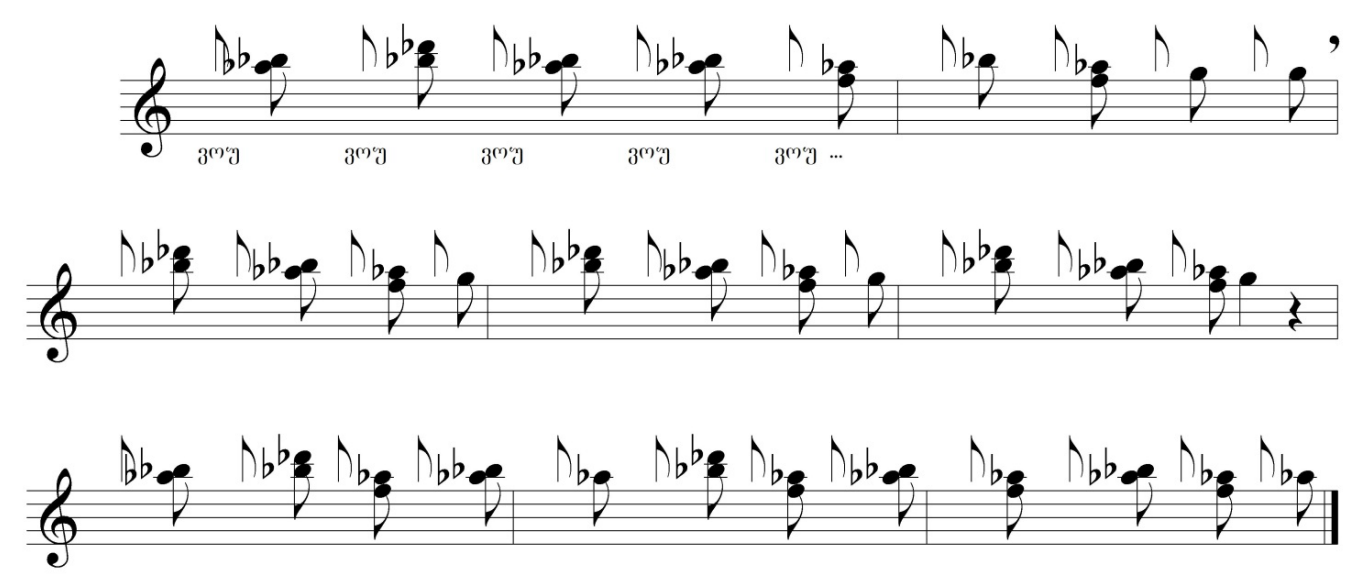

Score example 3.3. See the list of the notated instrumental pieces, \#13. Musical ex. \#13. 


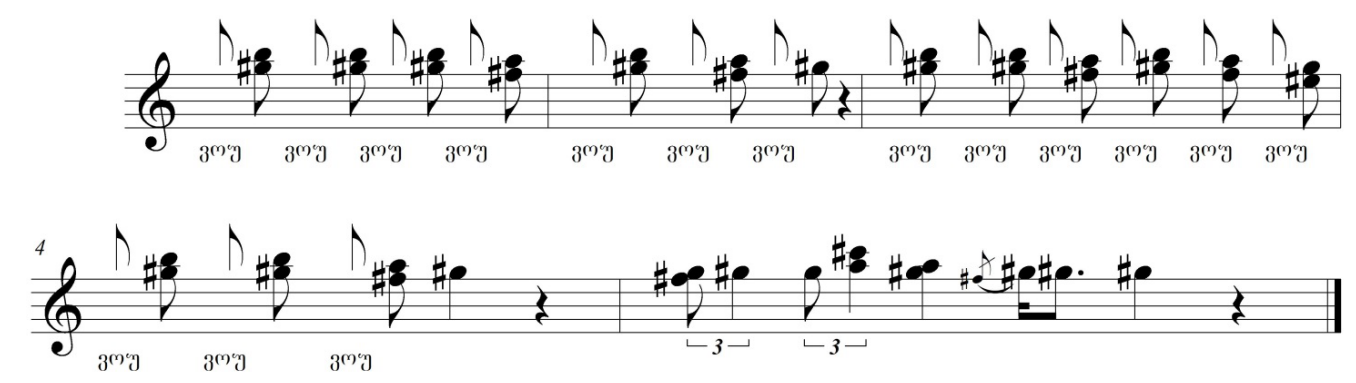

Score example 3.4. See the list of the notated instrumental pieces, \#14. Musical ex. \#17

At the beginning of my work with tunings I grouped audio samples recorded at different times and played by different performers. It was obvious that Dzokia Aronia's repertoire was recorded by K. Rosebashvili (1958) and O. Chijavadze (1959), and that only one player of soinari, Varden Meparishvili, was recorded by Sh. Mshvelidze (1931), V. Steshenko-Kuptina (1936) and K. Rosebashvili (1959). It turns out that the same performers were playing the same repertoire but using different instruments with different tunings in recordings from different years. Some of them almost exactly match the tunings and hertz measurements by Steshenko-Kuptina and the audio samples resurrected by the computer - I made an experiment on soinari repertoire recorded by this researcher, creating the audio versions of the fragments according to the hertz noted in these repertoires, which allowed me to listen to the real sound of the notated samples (audio example $\underline{33}-\underline{39}$ ). ${ }^{22}$

The question inevitably arises: how can all of seven tunings of the soinari, recorded at different times, be independent and different from each other, if the performer plays the same repertoire but at different times? We should take into consideration the fact that sometimes these musical pieces do not sound precisely just like as any musical piece sounds on the instrument with no tuning.

We concluded that the various tunings available to us have the same basic principle and that the differences between them are connected to the damage to the instrument arising from different technical or objective causes. While notating the musical material and defining the tunings I took these flaws into account and tried to cause the repertoire to sound as I thought it had sounded before the instrument damage occurred (score example 4: 1-10).

22 I wish to thank Levan Veshapidze, who did the experiment. The sound timbre of the audio samples was taken from the audio recordings by Mshvelidze. 

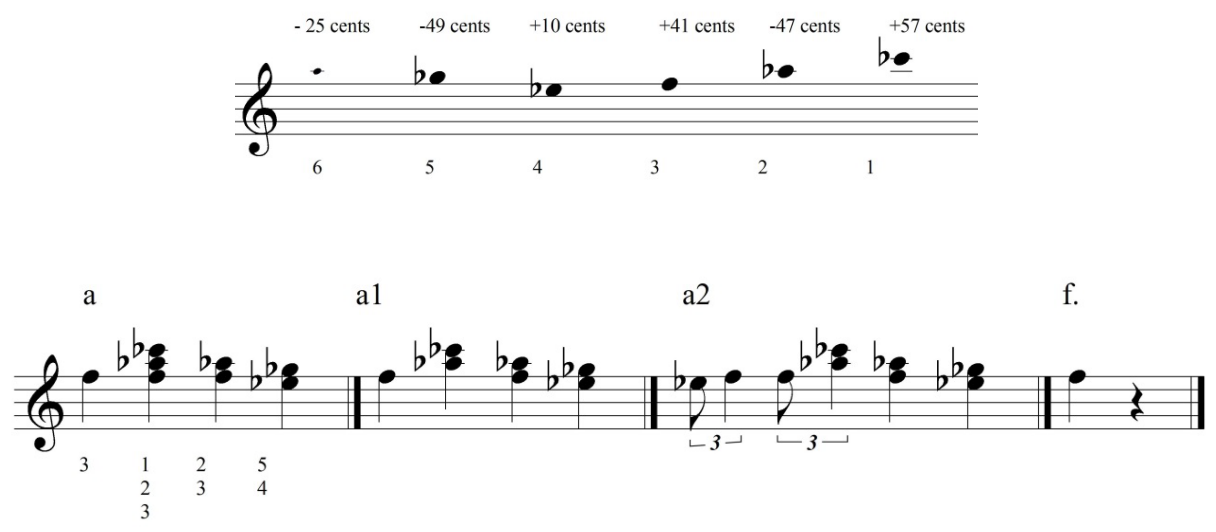

a, a, a1, a1, a1, a1, fin, a2, f.

Score example 4.1. $1^{\text {st }}$ tuning and $1^{\text {st }}$ instrumental piece (see audio ex. $\underline{8}, \underline{9}$ ).

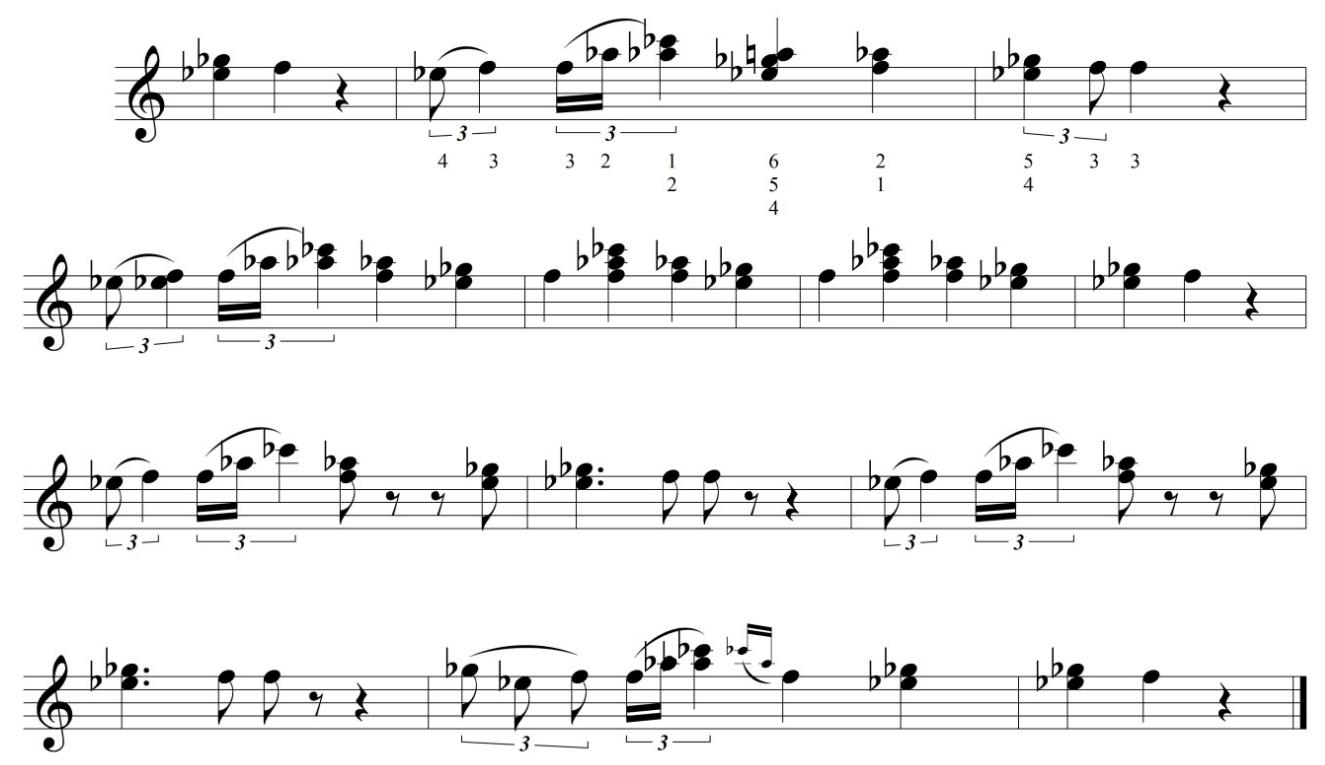

Score example 4.2. $2^{\text {nd }}$ instrumental piece in $1^{\text {st }}$ tuning (see audio ex. 10 ) 

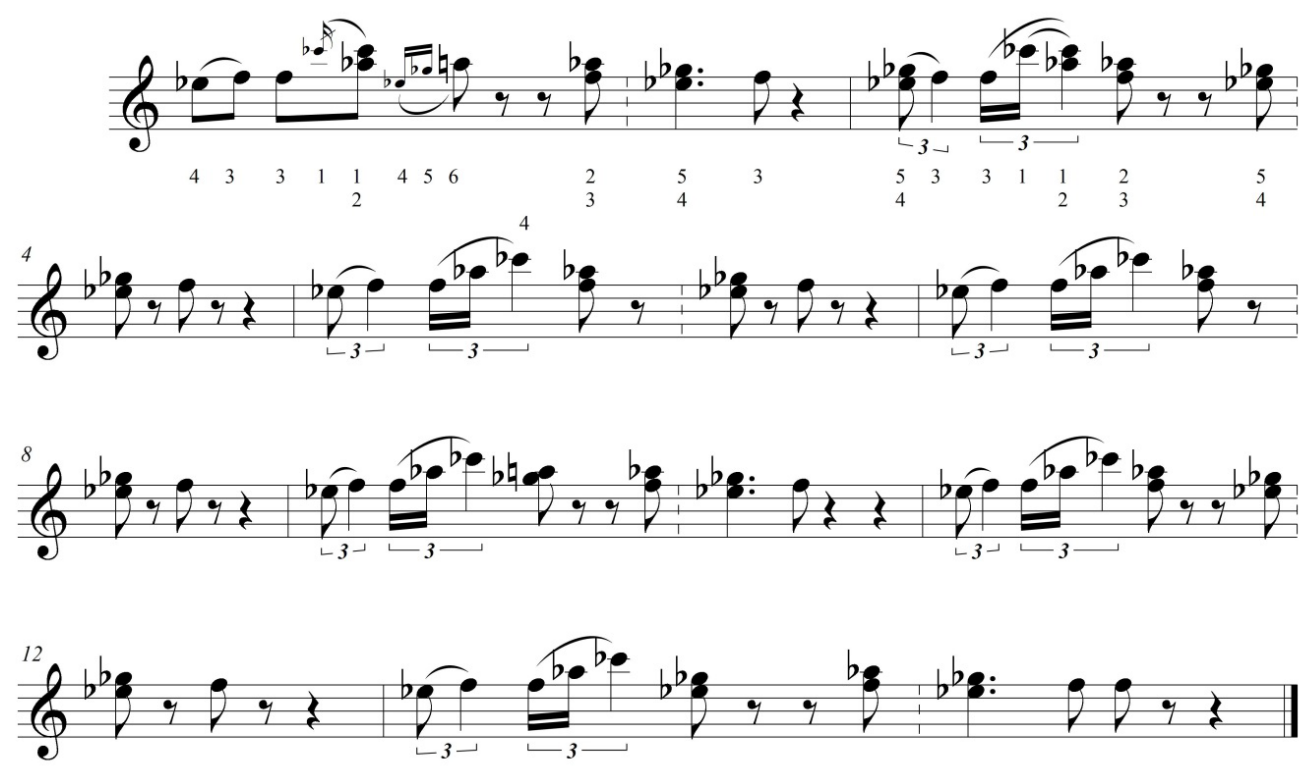

Score example 4.3. $3^{\text {rd }}$ instrumental piece in $1^{\text {st }}$ tuning (see audio ex. 11 , score ex. 3.1 )
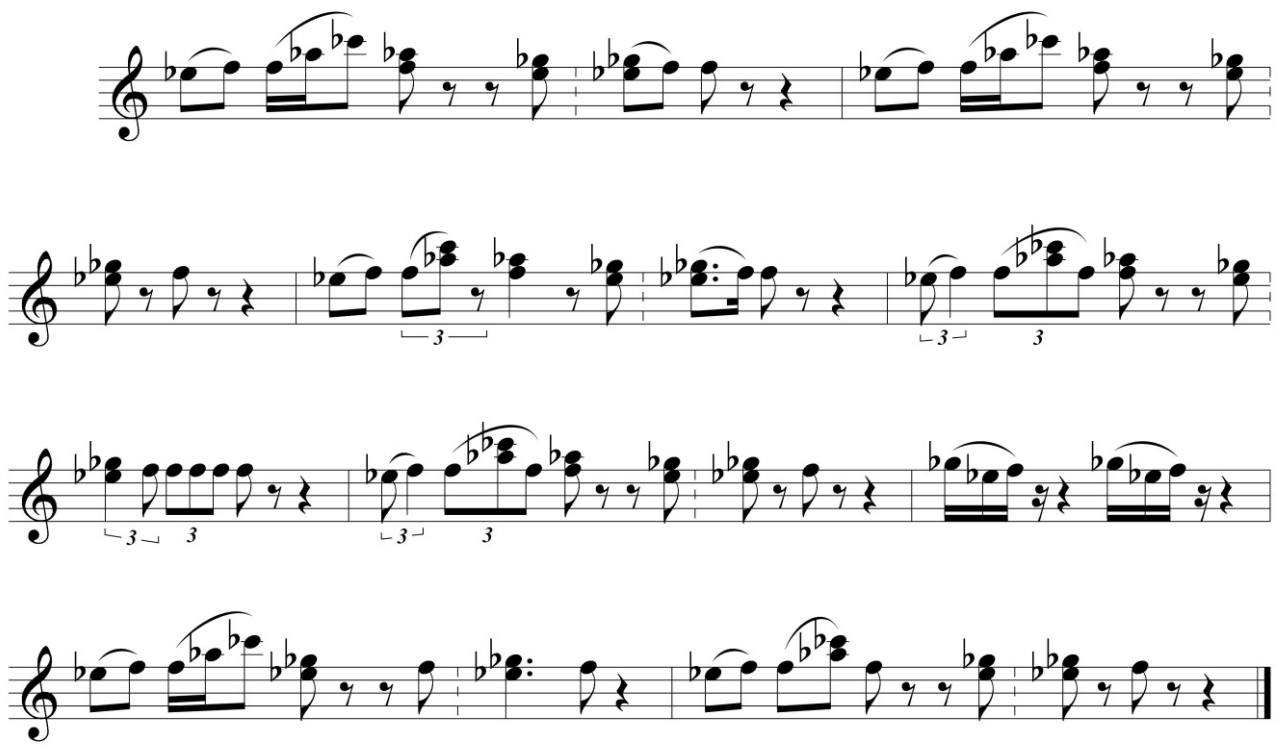

Score example 4.4. $4^{\text {th }}$ instrumental piece in $1^{\text {st }}$ tuning (see audio ex. $\underline{12}$ ) 

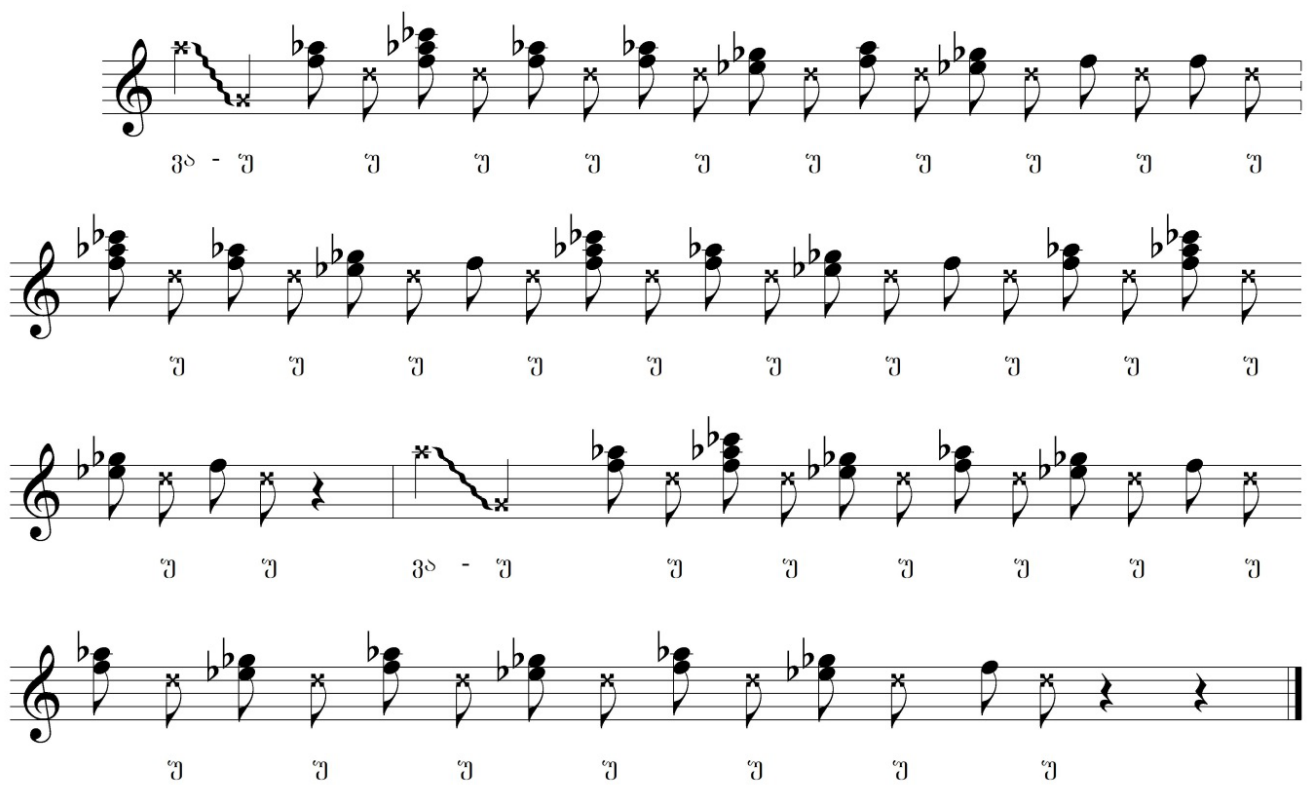

Score example 4.5. $5^{\text {th }}$ instrumental piece in $1^{\text {st }}$ tuning (see audio ex. 13 , score ex. 3.3)
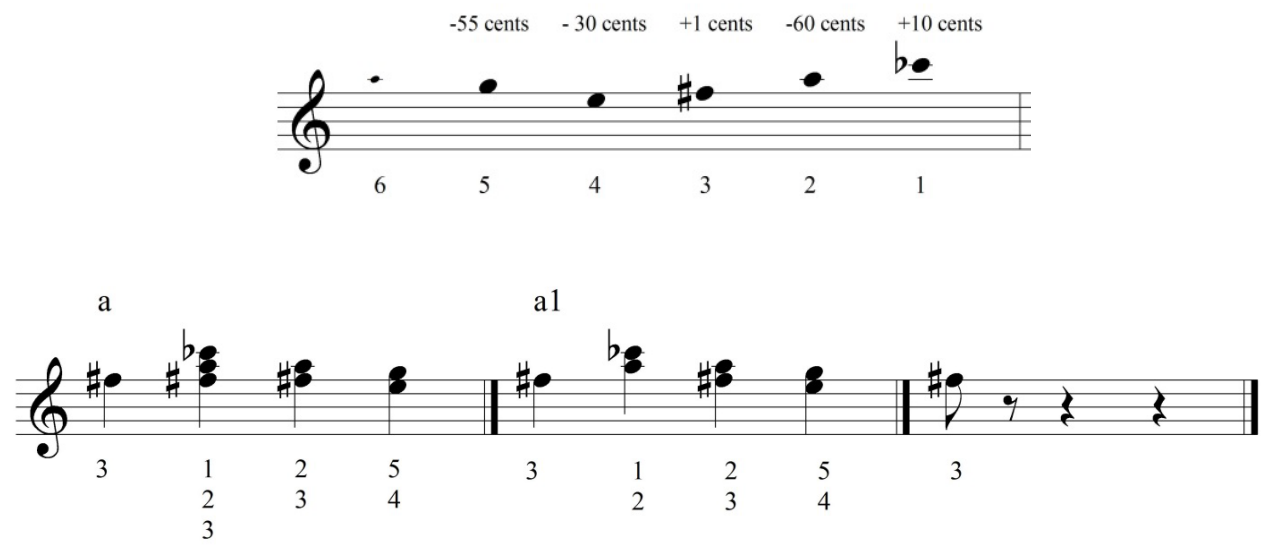

a a a1 a a a a a a a

Score example 4.6. $2^{\text {nd }}$ tuning and $1^{\text {st }}$ instrumental piece (see audio ex. $\underline{14} \underline{15}$ )

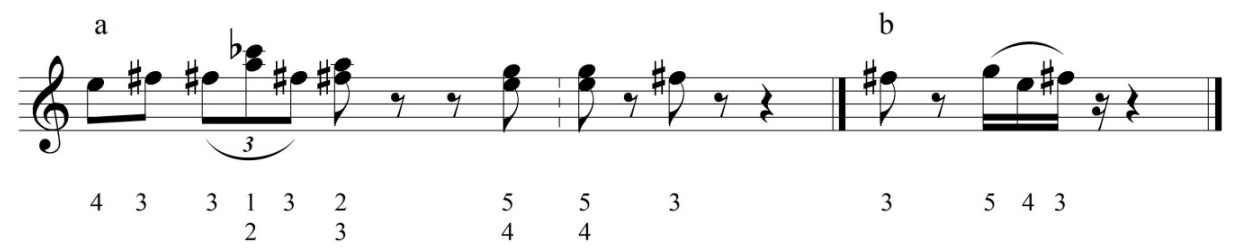

a a a a b a

Score example 4.7. $2^{\text {nd }}$ instrumental piece in $2^{\text {nd }}$ tuning (see audio ex. 16 , score ex. 3.2) 

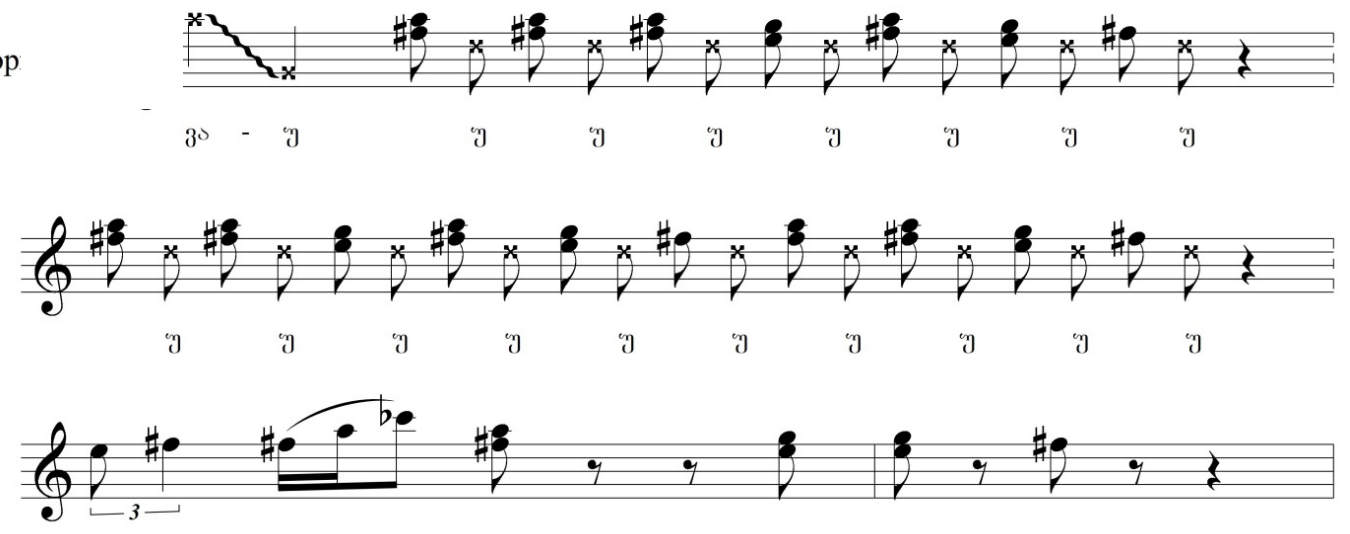

Score example 4.8. $3^{\text {rd }}$ instrumental piece in $2^{\text {nd }}$ tuning (see audio ex. 17 , score ex. 3.4 )
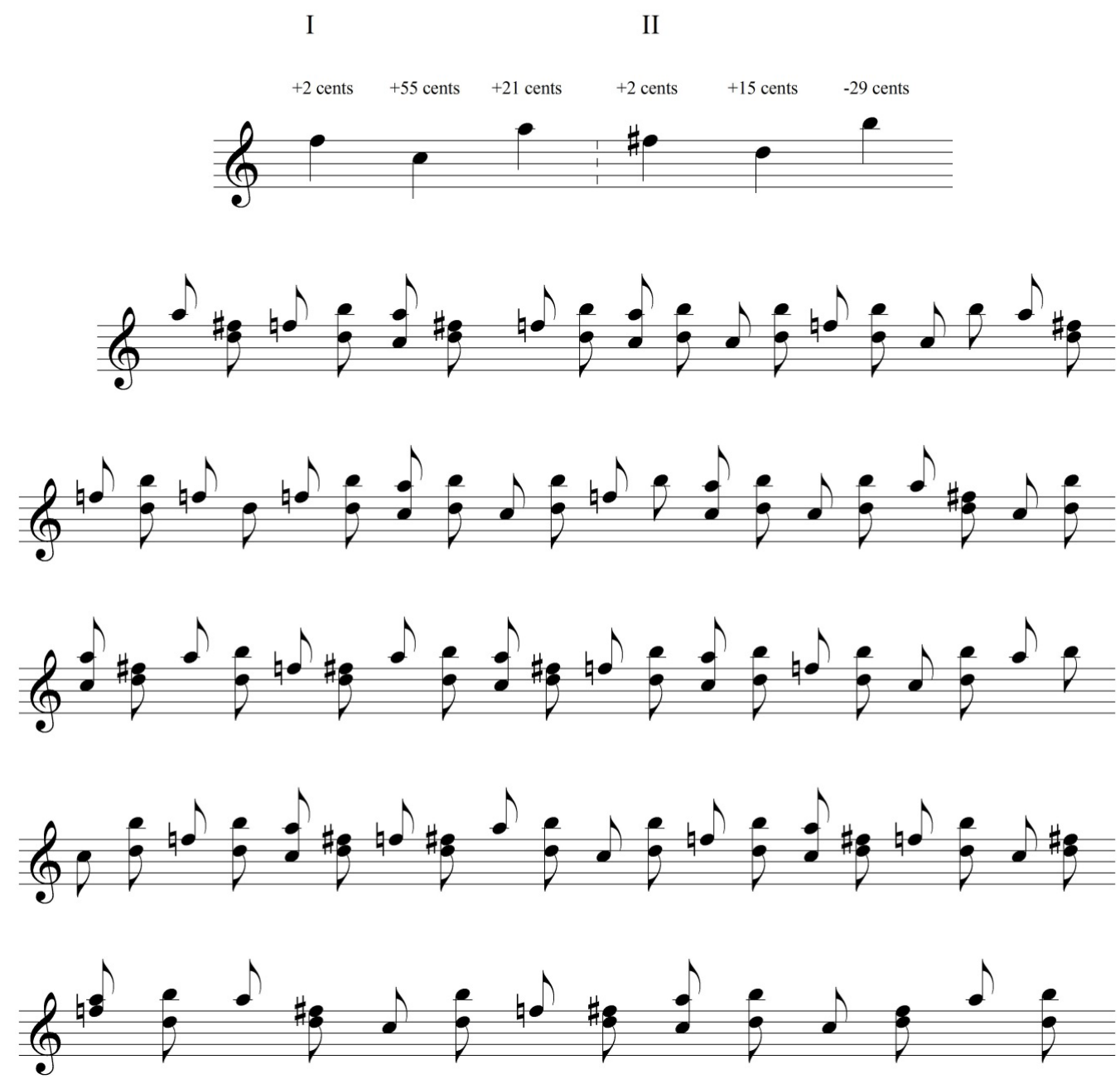

Score example 4.9. $4^{\text {th }}$ tuning and $3^{\text {rd }}$ 'Nirzi' (see audio ex. 22 24 ; score ex. 5.3) 

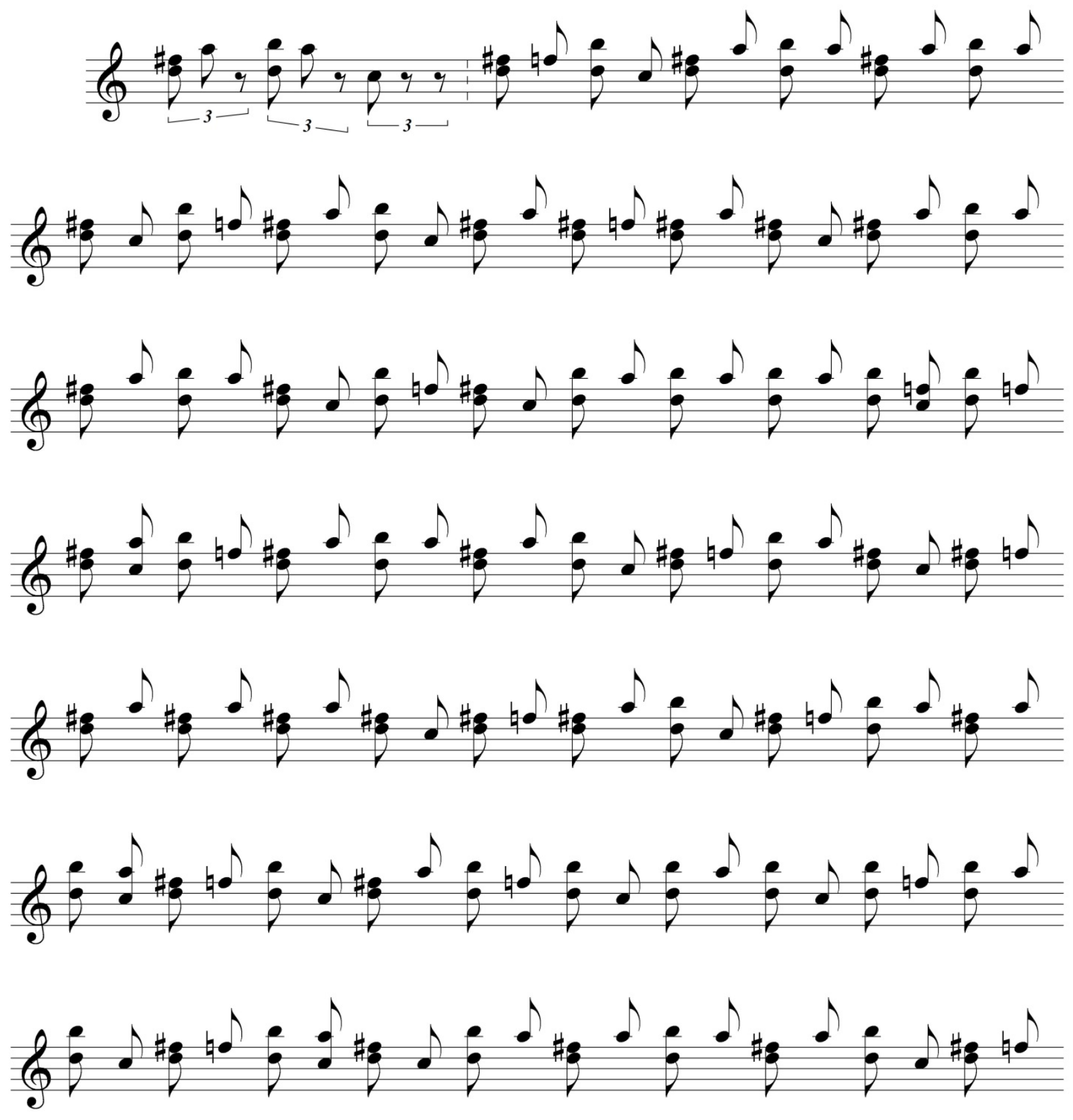

Score example 4.10. $4^{\text {th }}$ 'Nirzi' in $4^{\text {th }}$ tuning (see audio ex. $\underline{23}$ )

\section{Social Function and Repertoire}

We have more information about the larchemi's social functions and repertoire than about those of the soinari. From the examples of larchemi repertoire available to us, there are three ensemble pieces - 'Nirzi'; solo instrumental pieces recorded by Rosebashvili are mainly 'Mtskemsuri', and most of the pieces recorded by SteshenkoKuftina are dance examples. 
The larchemi is considered to be the instrument of shepherds in Georgia. There is documentation about three ways of playing it, related to herding the cattle: first while going to pasture, second while grazing, and third while coming back home (SteshenkoKuptina, 1936: 211). In addition, villagers played the larchemi during weddings and while marching after the overnight rituals of religious holidays (Makalatia, 1941: 257). The larchemi was also used to heal the sick through the ritual of 'catching the soul', in which four Megrelian players participated. In this case the voice of the larchemi (which sounds like someone whistling) was considered to represent the soul of the dead, and the instrument was used to summon or catch the soul (Rosebashvili, 1960: 51).

The Gurian soinari was connected to farming and traveling, especially traveling at night. As researchers note, this may be related to the ancient Greek habit of refraining from playing during the daytime so as not to awake the god Pan (Steshenko-Kuptina, 1936: 214-215).

According to the notes recorded by Steshenko-Kuptina, villagers played the larchemi with the daira (frame drum) and Svanetian chianuri, (bowed lute). Also, in the ceremony after Holy Thursday, they played it with the daira and wooden trumpet (SteshenkoKuptina, 1936: 210).

There was a form of competition between two larchemi players in Samegrelo called 'Nirzi', an instrumental dialogue, in which two performers divided the instrument into two $(3+3)$ and competed with each other. The winner was the one who played different tunes longer (Steshenko-Kuptina, 1936: 209; Makalatia, 1941: 257; Rosebashvili, 1960: 50-51). When the larchemi was divided into two, each set of three pipes was arranged so that the longest one was located in the middle.

\section{Analysis of the Musical Samples}

The range of repertoire for the larchemi and soinari matches the range of their tunings. The lowest (fourth pipe) and the highest (first pipe) are used in all of the pieces. Hence, the range of the repertoire may be the interval of a sixth or seventh ( $5^{\text {th }}-1^{\text {st }}$ pipes), while the stable intonation frame is within the perfect fourth $\left(5^{\text {th }}-2^{\text {nd }}\right.$ pipes).

Vertical harmony is mostly based on the movement of thirds. There are no seconds. Based on the tuning, to produce a second one would have to simultaneously play both of 
the bass pipes ( $4^{\text {th }}$ and $3^{\text {rd }}$ ), although, as I mentioned above, these pipes are never heard at the same time, as they match the $7^{\text {th }}$ and the $1^{\text {st }}$ steps of the scale. It is noted in the scholarly literature that three-voice polyphony can be heard only in questionable and fragmentary form on Georgian panpipes (Zhghenti, 2017: 202), although, when we studied the audio material, it was evident that there was also a real three-voice polyphony (audio example $\underline{40}$ ).

Pieces for the Georgian panpipe have a cyclical form ${ }^{23}$ (there are no contrasting sections, but there are signs of cyclical variation ${ }^{24}$ ); the form is always open, and the duration of the piece depends on the performer.

In the repertoire of the instruments with limited pitch and harmony, dramaturgical development is achieved via the following methods: alternating time signatures between 2/4 and 3/4; changing the vertical harmony in the same stanzas (playing vertical chords consisting of two or three notes on the same beat of the bar and intervals or three-note chords sounding simultaneously, as well as in arpeggio form); syncopated or accented rhythm; and finally, shouts inserted after each quarter in the identical melodic formulas. As for the pieces with shouts, the shouts appear in the culminating sections of the cycling form, after certain parts of the cycle, and provide optimum dynamic development. These are not individualized melodies, but non- individualized short intonation formulas characteristic of archaic musical thinking, the ostinato-variation repetition of which creates phrases and stanzas. Signs of heterophony are also apparent.

In the three notated recordings of the 'Nirzi' available to us (score example 5: 1-3), we see that five larchemis out of six had three pipes, and only one had six pipes (score example 5: 2). This instrumental piece is, in my opinion, an unsuccessful musical experiment, for three reasons. First, an atypical composition of the pipes is used $-6+3$ (according to the informant, two parts of one instrument must be used here to get the appropriate sound). Second, registers of the six-pipe and three-pipe flutes are significantly different. Third, one of the performers was young and inexperienced, and struggled with tuning the pipes.

\footnotetext{
${ }^{23}$ Steshenko-Kuptina united the samples of Varden Meparishvili as cyclical form and noted that this proves that panpipe was a highly developed instrument (Steshenko-Kuptina, 1936: 213).

${ }^{24}$ Cyclical variation form is characteristic of Georgian instrumental music, for example, in the repertoires of the chonguri (bowed lute), panduri (plucked lute), chiboni (bagpipe), etc.
} 


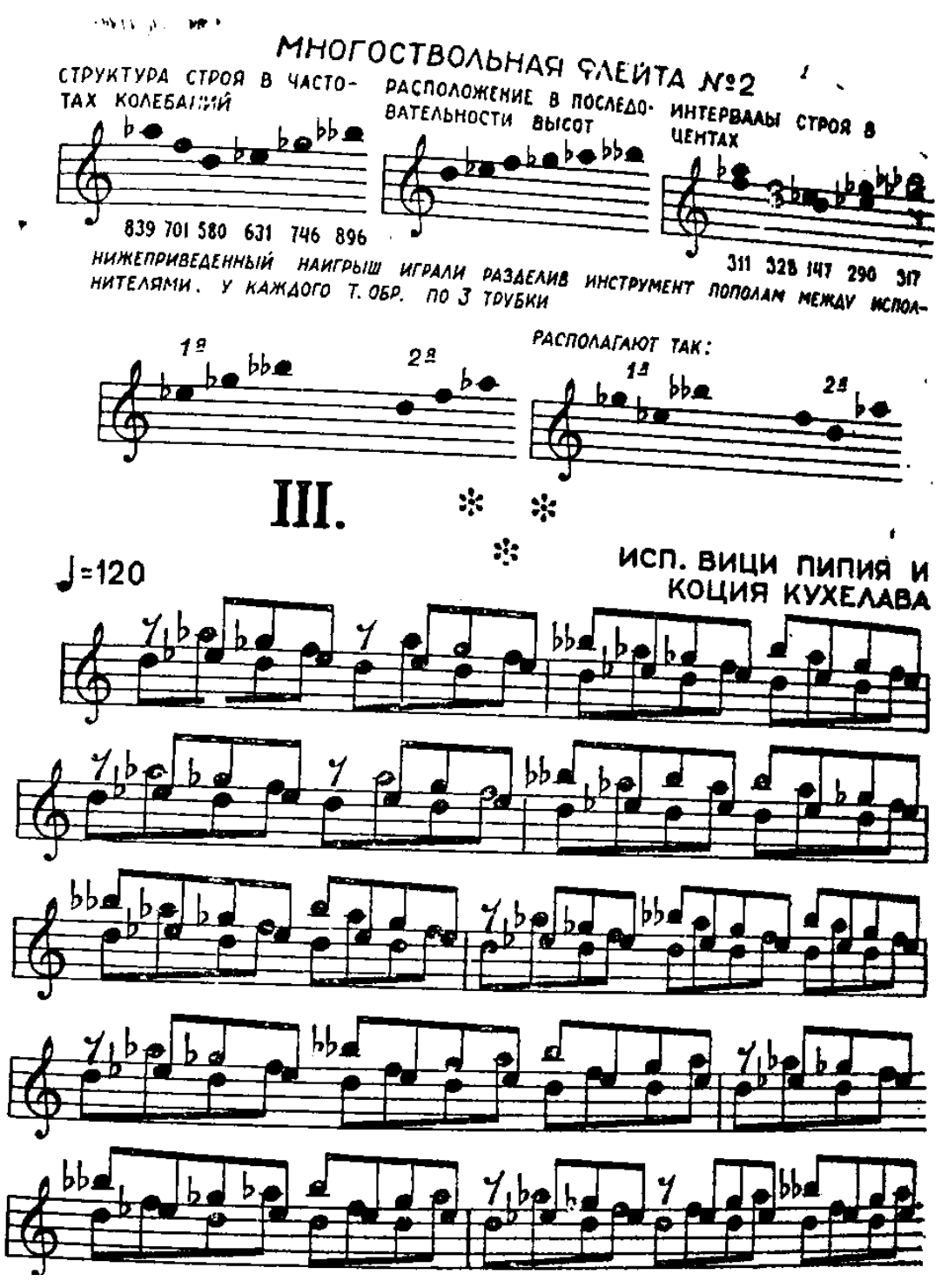

Score example 5.1. $1^{\text {st }}$ 'Nirzi' (Steshenko-Kuptina, 1936: 275) 


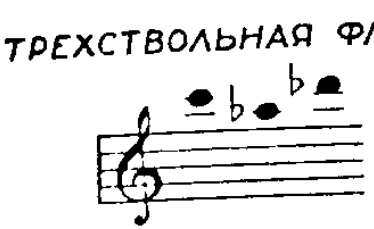

MHOГОСТВOАВНАЯ ФАЕЙTA N 21

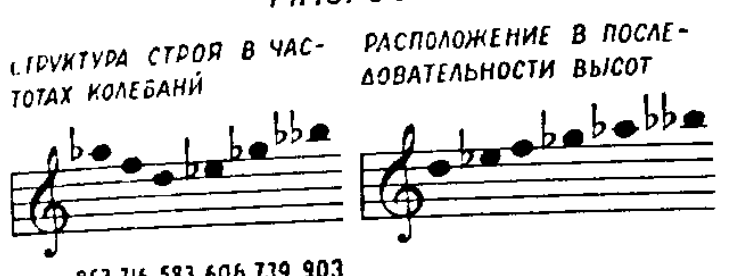

863716583606739903

ИHTEPBAПD СTPOA B

LEHTAX

\section{VI. ОСХАПУРИ}
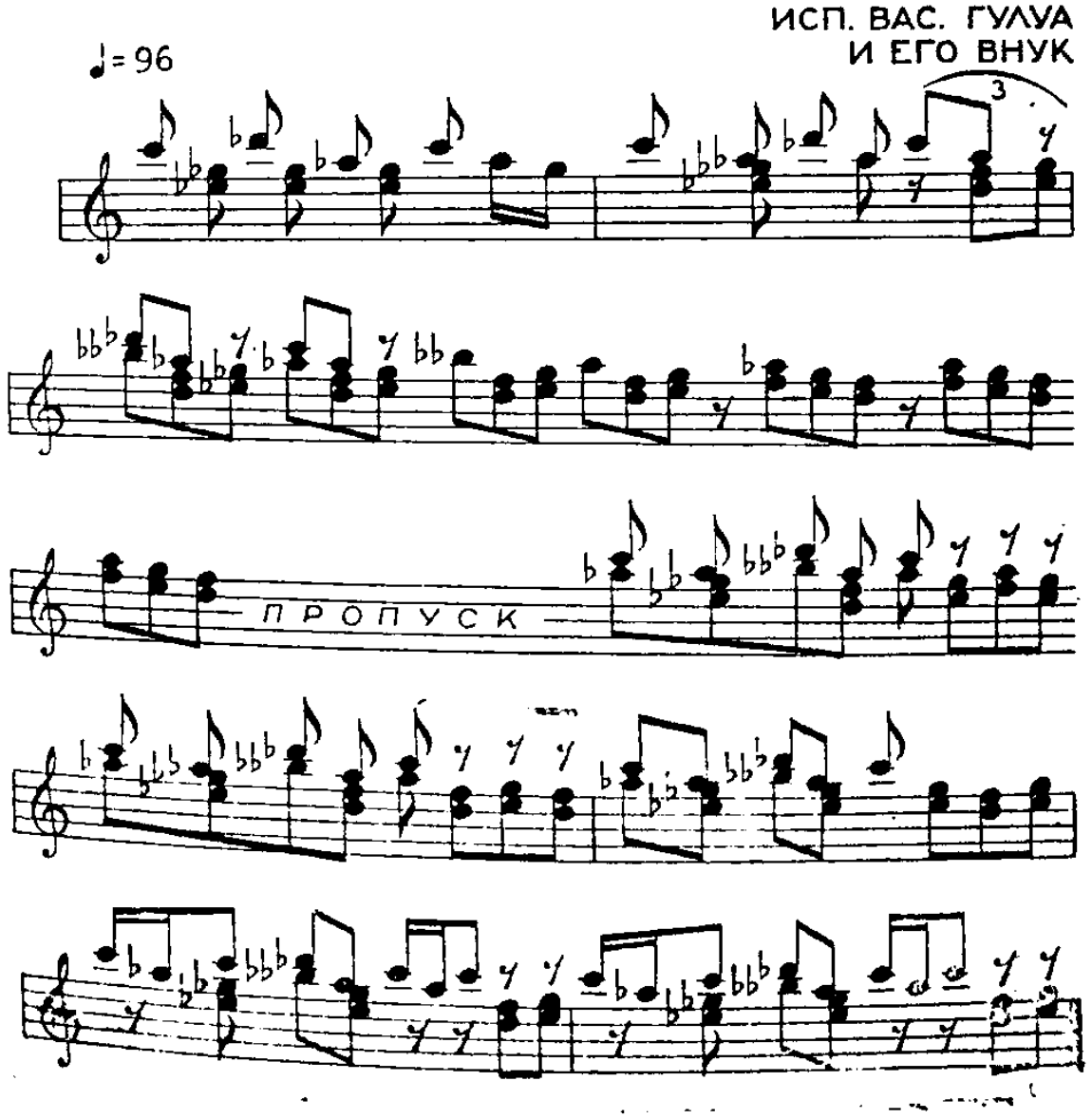

Score example 5.2. $2^{\text {nd }}$ 'Nirzi' (Steshenko-Kuptina, 1936: 277) 


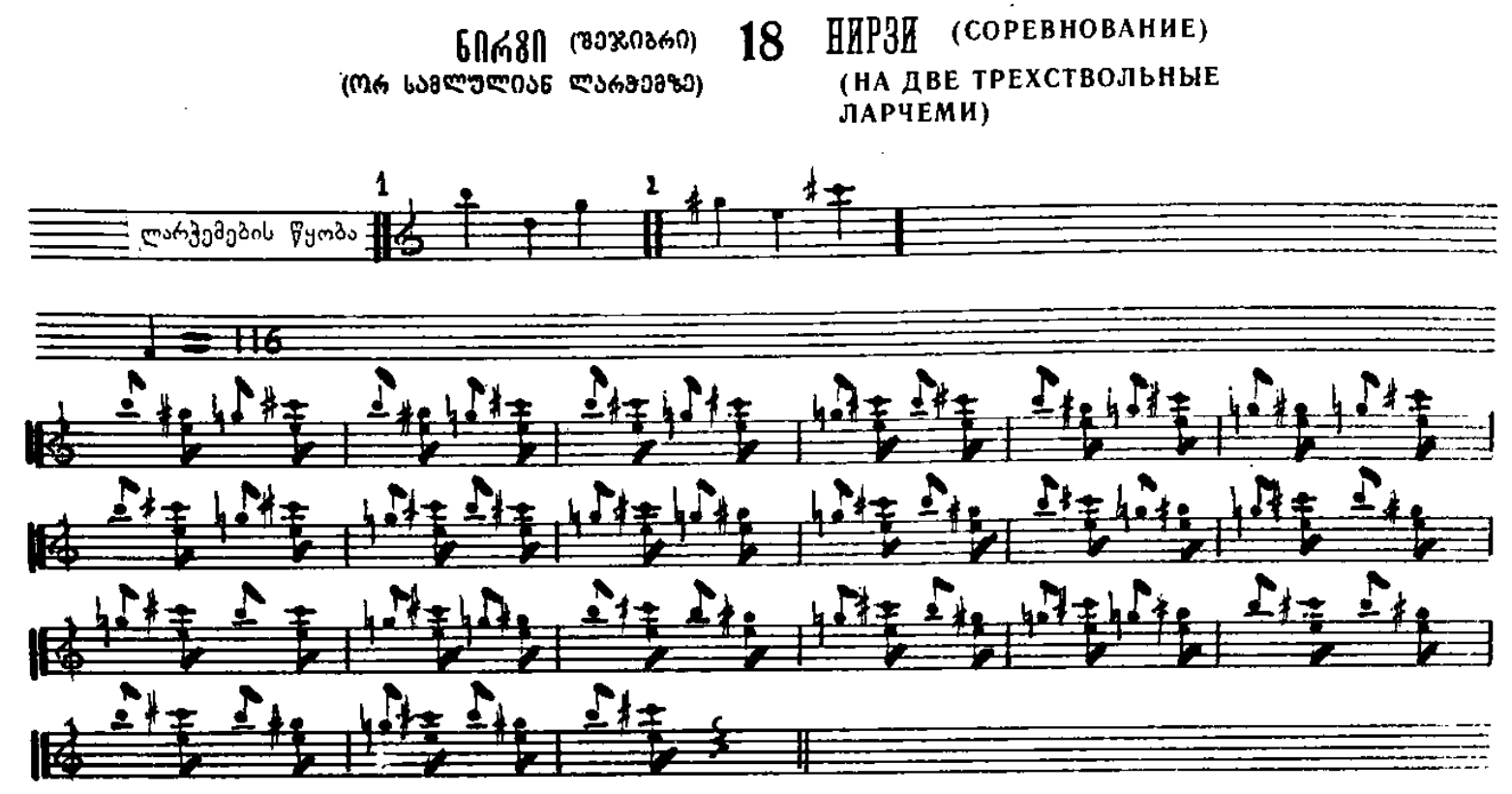

Score example 5.3. $3^{\text {rd }}$ Nirzi' (Rosebashvili, 1981: 46; see score ex. 4.9)

K. Rosebashvili noted that the tuning and compositions of the larchemi preserved to date have little in common with the laws of general Georgian vocal style (Rosebashvili, 1986: 16). However, many aspects of construction and repertoire reveal several indications of this connection:

- $\quad$ The names of the pipes, functionally matching the sounds they produce;

- Movement via parallel thirds, which is characteristic of complex polyphony (Shilakadze, 1970: 68);

- $\quad$ Matching of the intensively used pipes to the $7^{\text {th }}-1^{\text {st }}-2^{\text {nd }}-3^{\text {rd }}$ steps;

- Matching of the bass pipes and $1^{\text {st }}$ and $7^{\text {th }}$ steps of the scale, and intensive use of them in a similar context;

- $\quad$ Altering of the sound of the pipe called krimanchuli/tsvrili in tunings of different instruments;

- $\quad$ The fifth pipe matching the second step, sounding only with the fourth pipe matching the $7^{\text {th }}$ step of the scale. 
After studying the musical material it was possible to classify the repertoire of the panpipe, based on specific criteria, taking contemporary tendencies into consideration (table 5).

Table 5. Classification of the repertoire of the panpipe, based on specific criteria

\begin{tabular}{|c|c|c|c|}
\hline Criterion & \multicolumn{3}{|c|}{ Larchemi/Soinari repertoire } \\
\hline Genre & $\begin{array}{l}1 . \\
2 . \\
3 . \\
4 .\end{array}$ & \multicolumn{2}{|l|}{$\begin{array}{l}\text { Shepherd } \\
\text { Dance piece } \\
\text { Without clear social function } \\
\text { Stage music (contemporary practice) }\end{array}$} \\
\hline \multirow[t]{2}{*}{ Form of performing } & & $\begin{array}{l}\text { Solo } \\
\text { Ensemble } \\
\text { Several ensembles of six-pipe } \\
\text { Iments } \\
\text { 'Nirzi': two three-pipe (one instrument } \\
\text { ed into two) instrument ensembles } \\
\text { Instrumental inserted in poetry }\end{array}$ & Instrumental \\
\hline & & $\begin{array}{l}\text { Three seven-pipe instruments with } \\
\text { g choir (contemporary practice) }\end{array}$ & $\begin{array}{l}\text { Vocal- } \\
\text { instrumental }\end{array}$ \\
\hline Musical form & & $\begin{array}{l}\text { One part } \\
\text { Cycle (variational cycle) } \\
\text { Contrast-compiled cycle }\end{array}$ & \\
\hline $\begin{array}{l}\text { Development } \\
\text { principle }\end{array}$ & \multicolumn{3}{|c|}{ Ostinato-variational, free ostinato } \\
\hline $\begin{array}{l}\text { Structure/type of the } \\
\text { polyphony }\end{array}$ & \multicolumn{3}{|c|}{ Heterophony, ostinato } \\
\hline Scale & \multicolumn{3}{|c|}{$\begin{array}{l}\text { 1. Diminished scale, with scale centre: } \\
\text { 1.1. On the third pipe } \\
\text { 1.2. On the fourth pipe } \\
\text { 2. Sonorous scale }\end{array}$} \\
\hline Cadence & & \multicolumn{2}{|l|}{$\begin{array}{l}\text { Open } \\
\text { Closed }\end{array}$} \\
\hline Tuning & \multicolumn{3}{|c|}{$\begin{array}{l}\text { Diminished three-note chords. Distance between bass pipes: } \\
\text { 1. } \quad \text { Minor second } \\
\text { 2. } \quad \text { Major second } \\
\text { 3. } \quad \text { Augmented second }\end{array}$} \\
\hline Diapason & & \multicolumn{2}{|c|}{$\begin{array}{l}\text { Sixth } \\
\text { Seventh }\end{array}$} \\
\hline Performing technique & & \multicolumn{2}{|l|}{$\begin{array}{l}\text { With shouts (dasakviri) } \\
\text { Without shouts }\end{array}$} \\
\hline Number of pipes used & & \multicolumn{2}{|l|}{$\begin{array}{l}5 \text { pipes } \\
6 \text { pipes }\end{array}$} \\
\hline
\end{tabular}




\section{Conclusion}

The Georgian panpipe is one of an ancient pieces of the Georgian instrumentarium. It stands out among the world's pan flutes with its original construction and polyphonic mode of performance. Despite the fact that the instrument has disappeared from everyday life, the scores and audio sources available to us, has allowed me to research the unknown features of the instrument, such as tuning and performance issues.

Some people in Samegrelo wish to restore the instrument to performance. I think it is possible that the methodology of notation of the score and audio sources available to us that I have provided could be the beginning of the revival of the instrument.

\section{REFERENCES}

Abuladze, Ilia (ed.). (1964). Udzvelesi redaktsiebi basili kesarielis "ekusta dghetaisa" da grigol noselis targmanebisa "katsisa agebulebisatvis" X-XIII ss-is khelnatserta mikhedvit ("Ancient editions of "Six Days of Creation" by Basili of Caesaria translated by Gregory Nyssa's, taken from $10^{\text {th }}-13^{\text {th }}$ centuries manuscripts Nino"). Tbilisi: Metsniereba.

Chijavadze, Otar. [audiorecorder] (1959). Fieldwork in Samegrelo, tape \#82 [audio filed recordings of music]. Tbilisi: The Archive of Georgian Folk Music Laboratory of Tbilisi State Conservatoire.

Chikhladze, Vera. (2013). “Arkeologiuri gatkhrebis dros sakartveloshi aghmochenili musikaluri instrumentebi" (Musical Instruments Revealed in Georgia during the Archaeological Excavations) Iberia-kolkheti - sakartvelos klasikuri da adremedievuri periodis arkeologiur-istoriuli kvlevani (Iberia-Colchis, Researches on the Archaeology and History of Georgia in the Classical and Early Medieval Period). 9: 88-100. Tbilisi: Georgian National Museum, Journal of Otar Lortkipanidze Centre of Archaeology.

Chkhikvadze, Grigol. (2014). "Panpipe: 5. Central Europe and Asia”. The Grove Dictionary of Musical Instruments, Second Edition. 4: 20.

Civallero, Edgardo. (2014). Flautas de Pan de Europa (Panflute of Europe). Madrid: Edgardo Civallero 
Dvoretski, Iosip Khananovich (comp.). (1958). Drevnegrechesko-russkiy slovar' (Ancient Greek-Russian Dictionary), vol. II. Moskva: Gosudarstvennoye izdatel'stvo inostrannykh i natsional'nykh slovarey.

Janelidze, Dimitri. (1965). Kartuli teatris istoria (History of Georgian Theatre). Tbilisi: khelovneba. (In Georgian)

Javakhishvili, Aleksandre. (1958). “Khaishis gandzi” (Khaishi treasure). Mnatobi. 3: 149157.

Javakhishvili, Ivane. (1938). Kartuli musikis istoriis dziritadi sakitkhebi (The Basic Issues of Georgian Music History). Tbilisi: pederatsia.

Jzvania, Tinatin. (2006). [No title]. Materials for PhD thesis, manuscript. Stored in the Archive of the Folklore Laboratory of Tbilisi Conservatoire.

Kraveishvili, Giorgi. (2011). "Khalkhuri musikis etnograpiuli da musikalur-teologiuri aspektebi" (Ethnographic and Musical-Theological Aspects of Folk Music). BA diploma project, Tbilisi State Conservatoire. Tbilisi: Georgia.

MakalaTia, Sergi. (1941). Samegrelos istoria da etnograpia (History and Ethnography of Samegrelo).Tbilisi: sakartvelos mkharetmtsodneobis sazogadoeba.

Mshvelidze, Shalva. (2007). In Echoes from the Past: Georgian Folk Music from Phonograph Wax Cylinders 5. [CD]. Tbilisi: International Research Center for Traditional Polyphony of Tbilisi State Conservatoire.

Orbeliani, Sulkhan-Saba. (1940). Mogzauroba evropashi (Traveling in Europe). Prepared for publication by Solomon Iordanishvili. Tbilisi: Pederatsia.

Orbeliani, Sulkhan-Saba. (1993). Leksikoni kartuli (Georgian Dictionary). Prep. Abuladze, Ilia. Korneli Kekelidze Georgian National Centre of Manuscripts. Tbilisi: Merani.

Razmadze, Nino. (2014). “Larchemi”. The Grove Dictionary of Musical Instruments, Second Edition. 3: 260-261. 
Rosebashvili, Kakhi. [audiorecorder] (1958). Fieldwork in Samegrelo and Guria, tape \#99 [audio filed recordings of music]. Tbilisi: Archive of Georgian Folk Music Laboratory of Tbilisi State Conservatoire.

Rosebashvili, Kakhi. (1960). "Megruli larchemi" (Megrelian Larchemi) Sabchota khelovneba (Soviet Art). 7: 49-52. Tbilisi: sakartvelos ssr kulturis saministros organo.

Rosebashvili, Kakhi. (1975). "Dasavlet sakartveloshi gavrtselebuli chasaberi sakravebi”. (Aerophones Widespread in Western Georgia). Annual scholarly work, manuscripts. Stored in the Archive of the Folklore Laboratory of Tbilisi Conservatoire.

Rosebashvili, Kakhi. (1981). Kartuli khalkhuri simgherebi (Georgian Folk Songs) [Musical score]. Tbilisi: ssr kavshiris musikaluri pondis sakartvelos gankopileba.

Rosebashvili, Kakhi. (1985). "Kartuli chasaberi sakravebi: larchem-soinari, pilili da ugudo chiboni" (Georgian Aerophones: Larchemi and Soinari, Pilili and Chiboni without bag). Annual scholarly work, manuscripts. Stored in the Archive of the Folklore Laboratory of Tbilisi Conservatoire.

Rosebashvili, Kakhi. (1986). "Larchemi, pilili da ugudo chiboni" (Larchemi, Pilili and Chiboni without bag). Annual scholarly work, manuscripts. Stored in the Archive of the Folklore Laboratory of Tbilisi Conservatoire.

Saygun, Adnan. (1937). “Rize, Artvin ve Kars Havalisi: Türkü, Saz ve Oyunları Hakkında Bazı Malûmat" (Some Information about Folk Songs, Instruments and Dances of Rize, Artvin and Kars districts). Istanbul: Nümune Matbaası.

Sharashidze, Giorgi. (2014). Guruli leksikoni (Gurian Dictionary). Tbilisi: guriis sidzveleta kvlevis centri.

Shvelidze, Nina. (2003). "Georgian Multistemmed Salamuri - Larchemi /Soinari/" The I. International Symposium on Traditional Polyphony Proceedings 2002. [The $1^{\text {st }}$ International Symposium on Traditional Polyphony] Tsurtsumia, Rusudan; Jordania, Joseph (Eds.), (pp. 402-412). Tbilisi: International Research Center for Traditional Polyphony of Tbilisi State Conservatoire. 
Shilakadze, Manana. (1970). Kartuli khalkhuri sakravebi da sakravieri musika (Georgian Folk Instruments and Instrumental Music). Tbilisi: metsniereba.

Shilakadze, Manana. (2007). Traditsiuli musikaluri sakravebi da kartul-chrdilokavkasiuri etnokulturuli utrtiertobani (Traditional Musical Instruments and Georgian - North Caucasian Ethnocultural Relations). Tbilisi: kavkasiuri sakhli.

Simvulidi, Giorgi. (1978). "Kartuli khalkhuri chasaberi sakravebi” ("Georgian Folk Aerophones"). Diploma project, Tbilisi State Conservatoire. Tbilisi: Georgia.

Steshenko-Kuptina, Valentina (1936). Drevneyshiye instrumental'nyye osnovy gruzinskoy narodnoy muzyki, t. 1. Fleyta Pana (Ancient Instrumental Foundations of Georgian Folk Music. Vol. 1. Panpipe). Tbilisi: gosmuzei gruzii.

\section{List of Score and Audio Examples:}

\section{Notated instrumental pieces:}

1. Untitled. Larchemi. Performed by Vitsi Pipia. Chkvaleri, Samegrelo, recorded in 193? (Steshenko-Kuptina, 1936: 273, I).

2. Khasanbegura. Larchemi. Performed by Vitsi Pipia. Chkvaleri, Samegrelo, recorded in 193? (Steshenko-Kuptina, 1936: 274, II).

3. Untitled. Larchemi. Performed by Vitsi Pipia and Kotsia Kukhilava. Chkvaleri, Samegrelo, recorded in 193? (Steshenko-Kuptina, 1936: 275, III).

4. Oskhapuri. Larchemi. Performed by Vasil Gulua. Tskhakaia, Samegrelo, recorded in 193? (Steshenko-Kuptina, 1936: 276, IV).

5. Obireshi. Larchemi. Performed by Vasil Gulua. Tskhakaia, Samegrelo, recorded in 193? (Steshenko-Kuptina, 1936: 276, V).

6. Oskhapuri. Larchemi. Performed by Vasil Gulua and his son. Tskhakaia, Samegrelo, recorded in 193? (Steshenko-Kuptina, 1936: 277, VI).

7. First piece. Soinari. Performed by Varden Meparishvili. Tsipnari, Guria, recorded in 193? (Steshenko-Kuptina, 1936: 278, VIIA). 
8. Satsekvao (dance example). Soinari. Performed by Varden Meparishvili. Tsipnari, Guria, recorded in 193? (Steshenko-Kuptina, 1936: 278, VIIB).

9. Untitled. Soinari. Performed by Varden Meparishvili. Tsipnari, Guria, recorded in 193? (Steshenko-Kuptina, 1936: 278, VIIД).

10. Sasimghero (vocal example). Soinari. Performed by Varden Meparishvili. Tsipnari, Guria, recorded in 193? (Steshenko-Kuptina, 1936: 278, VIIC).

11. Mtskemsuri (shepherd's). Larchemi. Performed by Dzokia Aronia. Muzhava, Samegrelo, recorded in 1958 (Rosebashvili, 1975, 1981: 45, 1985: 4, 1986: 1). Audio instrumental piece \#10.

12. Mtskemsuri (shepherd's). Larchemi. Performed by Dzokia Aronia. Muzhava, Samegrelo, recorded in 1958 (Rosebashvili, 1986: 2). Audio instrumental piece \#16.

13. Mtskemsuri dadzakhili (Shepherd's, with exclamations). Larchemi. Performed by Dzokia Aronia. Muzhava, Samegrelo, recorded in 1958 (Rosebashvili, 1996: 3). Audio instrumental piece \#13.

14. Mtskemsuri dasakviri (shepherd's, with exclamations). Larchemi. Performed by Dzokia Aronia. Muzhava, Samegrelo, recorded in 1958 (Rosebashvili, 1996: 3). Audio instrumental piece \#17.

15. Mtskemsuri (shepherd's). Larchemi. Performed by Gera Kukhilava. Chkvaleri, Samegrelo, recorded in 1958 (Rosebashvili, 1981: 45, 1985: 5, 1986: 5, I). Audio instrumental piece \#19.

16. Mtskemsuri (shepherd's). Larchemi. Performed by Gera Kukhilava. Chkvaleri, Samegrelo, recorded in 1958 (Rosebashvili, 1981: 45, 1985: 5, 1986: 6, II). Audio instrumental piece \#20.

17. Mtskemsuri (shepherd's). Larchemi. Performed by Gera Kukhilava. Chkvaleri, Samegrelo, recorded in 1958 (Rosebashvili, 1981: 46, 1985, 1986: 6, III). Audio instrumental piece \#21. 
18. Nirzi (competition). With two three-pipe larchemis. Performed by Gera and Grigol Kukhilavas. Chkvaleri, Samegrelo, recorded in 1958 (Rosebashvili, 1981: 46, 1985: 6, 1986: 4). Audio instrumental piece \#24.

19. Satsekvao (dance example). Soinari. Performed by Varden Meparishvili. Tsipnari, Guria, recorded in 1959 (Rosebashvili, 1985: [1]). Audio instrumental piece \#29.

20. Dasakravi (instrumental piece). Soinari. Performed by Varden Meparishvili. Tsipnari, Guria, recorded in 1959 (Rosebashvili, 1985: [2]). Audio instrumental piece \#28.

21. Dasakravi (instrumental piece). Soinari. Performed by Varden Meparishvili. Tsipnari, Guria, recorded in 1958 (Rosebashvili, 1985: [1]). Audio instrumental piece \#27.

\section{Audio examples:}

1. Tuning (I). Soinari. Performed by Varden Meparishvili. Kokhnari, Chokhatauri, recorded in 1931 (Mshvelidze, 2007: CD5, \#18), 0:39.

2. Dasakravi (instrumental piece in I tuning). Soinari. Performed by Varden Meparishvili. Tsipnari, Guria, recorded in 1931 (Mshvelidze, 2007: CD5, \#16), 0:30.

3. Dasakravi (instrumental piece in I tuning). Soinari. Performed by Varden Meparishvili. Tsipnari, Guria, recorded in 1931 (Mshvelidze, 2007: CD5, \#17), 1:32.

4. Dasakravi shedzakhilebit (instrumental piece with exclamations in I tuning). Soinari. Performed by Varden Meparishvili. Tsipnari, Guria, recorded in 1931 (Mshvelidze, 2007: CD5, \#20), 0:35.

5. Gr. Sharabidze's Tuning (II). Soinari. Performed by Varden Meparishvili. Tsipnari, Guria, recorded in 1931 (Mshvelidze, 2007: CD5, \#21), 0:35.

6. Dasakravi (instrumental piece in big soinari, II tuning). Soinari. Performed by Varden Meparishvili. Tsipnari, Guria, recorded in 1931 (Mshvelidze, 2007: CD5, \#22), 2:05. 
7. Dasakravi (instrumental piece in big soinari, III tuning). Performed by Varden Meparishvili. Tsipnari, Guria, recorded in 1931 (Mshvelidze, 2007: CD5, \#19), 1:28.

8. Tuning (I). Larchemi. Performed by Dzokia Aronia. Muzhava, Samegrelo. Recorded by K. Rosebashvili, 1958 (the Archive of Georgian Folk Music Laboratory of Tbilisi State Conservatoire [AGFML], expedition tape \#99, 00:00-00:45), 0:41.

9. Dasakravi (instrumental piece, in I tuning). Larchemi. Performed by Dzokia Aronia. Muzhava, Samegrelo. Recorded by K. Rosebashvili, 1958 (AGFML, expedition tape \#99, 00:45-01:10), 0:22.

10. Dasakravi (instrumental piece, in I tuning). Larchemi. Performed by Dzokia Aronia. Muzhava, Samegrelo. Recorded by K. Rosebashvili, 1958 (AGFML, expedition tape \#99, 2:08-02:38), 0:29.

11. Dasakravi (instrumental piece, in I tuning). Larchemi. Performed by Dzokia Aronia. Muzhava, Samegrelo. Recorded by K. Rosebashvili, 1958 (AGFML, expedition tape \#99, 2:39-03:05), 0:26. Notated instrumental piece \#11.

12. Dasakravi (instrumental piece, in I tuning). Larchemi. Performed by Dzokia Aronia. Muzhava, Samegrelo. Recorded by K. Rosebashvili, 1958 (AGFML, expedition tape \#99, 03:05-03:32), 0:27.

13. Dasakravi (instrumental piece with exclamations, in I tuning). Larchemi. Performed by Dzokia Aronia. Muzhava, Samegrelo. Recorded by K. Rosebashvili, 1958 (AGFML, expedition tape \#99, 04:01-04:27), 0:22. Notated instrumental piece \#13.

14. Tuning (II). Larchemi. Performed by Dzokia Aronia. Muzhava, Samegrelo. Recorded by K. Rosebashvili, 1958 (AGFML, expedition tape \#99, 01:10-01:35), 0:11.

15. Dasakravi (instrumental piece, in II tuning). Larchemi. Performed by Dzokia Aronia. Muzhava, Samegrelo. Recorded by K. Rosebashvili, 1958 (AGFML, expedition tape \#99, 01:35-02:08), 0:33.

16. Dasakravi (instrumental piece, in II tuning). Larchemi. Performed by Dzokia Aronia. Muzhava, Samegrelo. Recorded by K. Rosebashvili, 1958 (AGFML, expedition tape \#99, 03:32-04:01), 0:28. Notated instrumental piece \#12. 
17. Dasakravi (instrumental piece with exclamations, in II tuning). Larchemi. Performed by Dzokia Aronia. Muzhava, Samegrelo. Recorded by K. Rosebashvili, 1958 (AGFML, expedition tape \#99, 04:27-04:42), 0:14. Notated instrumental piece \#14.

18. Tuning (III). Larchemi. Performed by Dzokia Aronia. Muzhava, Samegrelo. Recorded by K. Rosebashvili, 1958 (AGFML, expedition tape \#99, 06:28-06:52), 0:20.

19. I Mtskemsuri (shepherd's, in III tuning). Larchemi. Performed by Gera Kukhilava. Chkvaleri, Samegrelo. Recorded by K. Rosebashvili, 1958 (AGFML, expedition tape \#99, 06:52-07:30), 0:37. Notated instrumental piece \#15.

20. II Mtskemsuri (shepherd's, in III tuning). Larchemi. Performed by Gera Kukhilava. Chkvaleri, Samegrelo. Recorded by K. Rosebashvili, 1958 (AGFML, expedition tape \#99, 07:30-08:10), 0:39. Notated instrumental piece \#16.

21. III Mtskemsuri (shepherd's, in III tuning). Larchemi. Performed by Gera Kukhilava. Chkvaleri, Samegrelo. Recorded by K. Rosebashvili, 1958 (AGFML, expedition tape \#99, 08:10-08:53), 0:43. Notated instrumental piece \#17.

22. Tuning (IV). Larchemi. Performed by Gera and Grigol Kukhilavas. Chkvaleri, Samegrelo. Recorded by K. Rosebashvili, 1958 (AGFML, expedition tape \#99, 04:5505:17), 0:20.

23. I Nirzi (competition, in IV tuning). With two three-pipe larchemis. Performed by Gera and Grigol Kukhilavas. Chkvaleri, Samegrelo. Recorded by K. Rosebashvili, 1958 (AGFML, expedition tape \#99, 05:17-05:58), 0:41.

24. II Nirzi (competition, in IV tuning). With two three-pipe larchemis. Performed by Gera and Grigol Kukhilavas. Chkvaleri, Samegrelo. Recorded by K. Rosebashvili, 1958 (AGFML, expedition tape \#99, 05:58-06:28), 0:29. Notated instrumental piece \#18.

25. Tuning (IV). Soinari. Performed by Varden Meparishvili. Tsipnari, Guria. Recorded by K. Rosebashvili, 1959 (AGFML, expedition tape \#99, 12:41-13:31). 0:58.

26. Dasakravi (instrumental piece, fragment, in IV tuning). Soinari. Performed by Varden Meparishvili. Tsipnari, Guria. Recorded by K. Rosebashvili, 1959 (AGFML, expedition tape \#99, 09:20-10:15), 0:59. 
27. Dasakravi (instrumental piece, in IV tuning). Soinari. Performed by Varden Meparishvili. Tsipnari, Guria. Recorded by K. Rosebashvili, 1959 (AGFML, expedition tape \#99, 09:20-10:15), 0:59. Notated instrumental piece \#21.

28. Dasakravi (instrumental piece, in IV tuning, with singing). Soinari. Performed by Varden Meparishvili. Tsipnari, Guria. Recorded by K. Rosebashvili, 1959 (AGFML, expedition tape \#99, 11:16-11:09), 1:29. Notated instrumental piece \#20.

29. Dasakravi (instrumental piece, in IV tuning, with exclamations). Soinari. Performed by Varden Meparishvili. Tsipnari, Guria. Recorded by K. Rosebashvili, 1959 (AGFML, expedition tape \#99, 13:39-15:14), 1:44. Notated instrumental piece \#19.

30. Mtskemsuri (shepherd's, in V tuning). Larchemi. Performed by Varden Meparishvili. Muzhava, Samegrelo. Recorded by O. Chijavadze, 1959 (AGFML, expedition tape \#82:16), 1:13.

31. Mtskemsuri (shepherd's, in V tuning). Larchemi. Performed by Dzokia Aronia. Muzhava, Samegrelo. Recorded by O. Chijavadze, 1959 (AGFML, expedition tape \#82:13), 1:13.

32-39. The audio samples resurrected by the computer. $(32,33,34,35,36,37,38,39)$

40. The three-voice polyphony. 